\title{
SOME PROBLEMS OF TYMPANOPLASTY
}

\author{
By \\ Yasushi KOIDE, M.D. and Yoshio KOIKE, M.D. \\ Department of Otolaryngology Niigata University \\ School of Medicine (Head: Hatsuo Ino, M.D.)
}

Type 2 tympanoplasty showe astonishingly good results, because of the preservation of the large air space of the middleear cavity. The results of type 3 operation was rather poor in some cases with respect to hearing. But in the cases where inflammations are absent, the results have been good. Further the problem of drug-resistant bacteria has been emphazized. Generally speaking, the results of operation seemed to be poor in all plastic operations on the middle ear where drug-resistant bacteria are present.

Ossicular repositioning is advocated to preserve the air space of the middle ear cavity and insure more adequate transmission of sound to the stapedial footplate. Ossicular repositioning will convert a type 3 into a incudostapediopexy or malleolostapediopexy. We make it a rule not to introduce foreign bodies or free autobone graft into the inflammatory middle ear, due to the occurrence of vigorous tissue reactions. However in the absence of pathological condition, we can introduce polyethylene tubing to insure ossicular continuity or to create a artificial columella.

\section{鼓室成形術の諸問題}

新渴大学医学部耳學咽唤科教室（主任：猪初男教授）

小出靖少池吉郎

\section{緒言}

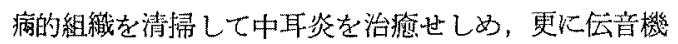
構の修復又は再建して㯖力改善を計るのが鼓至成形術の 2大眼目である。識者の云ら污如く，耳漏停止しなけれ ば畾力改善の目的は趡成し得ない。

しかしあまりにも病的組織の馀去に徾すれば乎術成續 は不良であり，反対に清掃不完全ならば中耳の化潂の根 䋓ができなくなる，雨者のか权合いが觐室成形上漫も苫 心するとこるで，諸家の見解が分かれるとこるでああ 子。

鼓室成形術はすで routine operation となつて拉 り，皮弁，削開の限界，鼓室粘膜の処理，伝音連鎖の临 復や再形成等多くの経験がつみ重小られてきた，特に後 2者では術者の経験的判断にまつところが多い，乙かし 鼓室成形術といえど, 術創は一般炎症治癒菬程の原則よ り外れるものでなく，手術手技の実施に際してはこれを
都慮の上でなさるべきである。

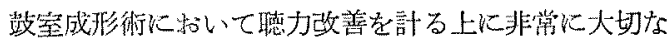
key point がめる。つ亦り䔩膜皮弁が耳小骨又はコル人 ラで卵円空と連絡し，卵円空周迊をも含めて鼓膜皮全と 蝸牛骨壁の間に含気䐩の形成があることが大切である。 このためにもをた術後の肉芽の発生を極力抑制するのが 大切で, 耳小骨尽コルメラの周辽に肉莱の発尘を惹起す るとすると㯖力改㦈は望めない

局所の術後性組織反心は手術時の組織の状態いかんに 左右さ狆，炎症の軽度なるほどとの反応は柽微に止ま る。李た骨面炎露出した場合肉芽の発生はさけ難く，粘 膜保存の埸合に比し不利なることは四に周知のことであ る、觐空成形術では術後性組織反広をいかにして最小限 度に上奶るが手術成續を大きく去可する。

炎症の根絶と聴力改善といら互火相反する要素のシラ

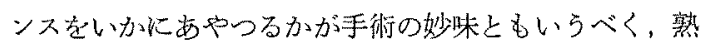




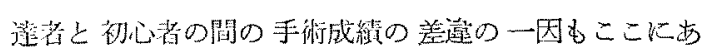

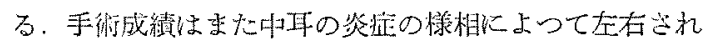

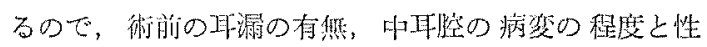

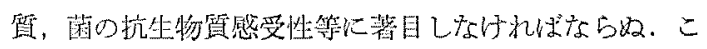

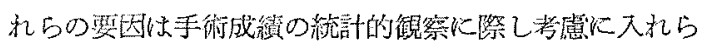

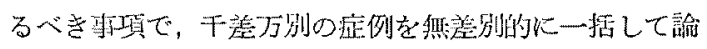
ビても㶵意味沉思克る。

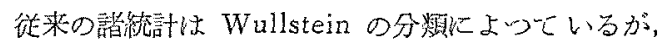

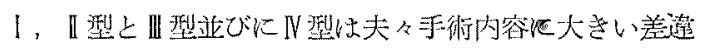

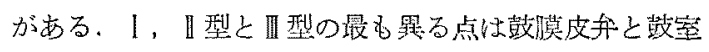

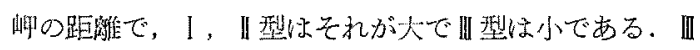

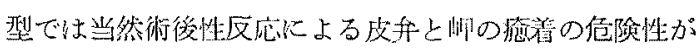
增してくる、N型では多くのものが病変高度であり，特 に正円惩筒の病変の処理が困難なことの外飞，cavum minor の確保が極めて困踓なことが知られている。

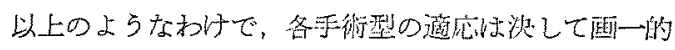

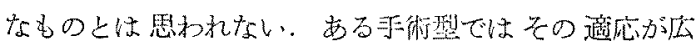
く，他の手術型はそれがすこぶる制限されよう。から に手術型の適応をはつきりざせるとは重要なことであ

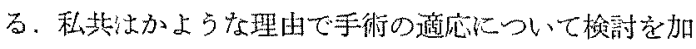
え，中耳焱の性状汇応じた乎術体系を作り上ぐべく計画 した、多数の術者による成縝の集計では術者の技術差が

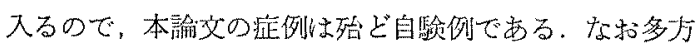

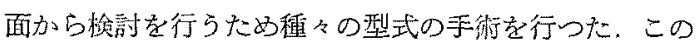
中に恃失敗予期して行つた症例も多い。

耳管通気度不良なもの之鼓室硬化店は今回の检討上り

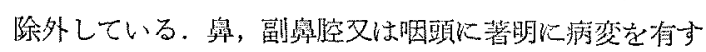
るものは，事前適切な治療を行つて軽快さしめてから 故室成形術老行つた。

耳消の多いものは鼓室成形術を一次的に行うことな

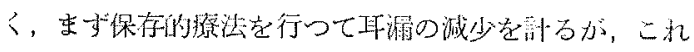

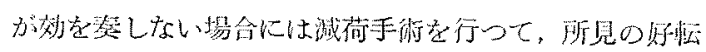
を密つて2 次的比政空成形術を罗施している。

\section{手術症例D菌梌索成繶}

故空成形術の施行にすたつては，術前，術得の炎庭の

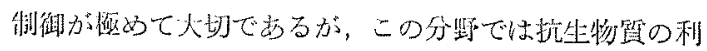
同が重要な役割在演する。私共の全定例小300耳で，こ の内菌を满出し得たものは163耳であつた。

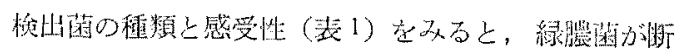
然多く，しか子抗生物留感受性がすこらる不艮なのが多 いことが注目される。こ机に次いで多いのはブドー球箱

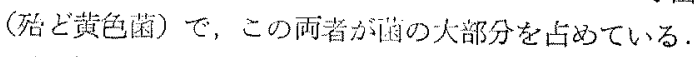

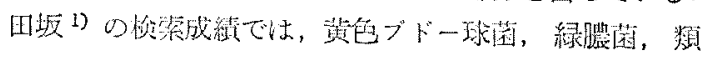

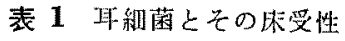

\begin{tabular}{|c|c|c|c|c|c|}
\hline \multirow{2}{*}{\multicolumn{2}{|c|}{ 淢 }} & \multirow{2}{*}{ 総株数 } & \multicolumn{3}{|c|}{ 抗生物留感受性 } \\
\hline & & & $H \sim H$ & + & - \\
\hline 啮 & 菌 & 81 & 32 & 13 & 36 \\
\hline ブドー 状理 & 菌 & 52 & 41 & 5 & 6 \\
\hline 形 & 菌 & 8 & 6 & 1 & 1 \\
\hline グラム䏂性柏 & 菌 & 7 & 3 & 0 & 4 \\
\hline グラム㓌性桿 & 菌 & 10 & 5 & 0 & 5 \\
\hline グラム㯦性理 & 菌 & 5 & 4 & 0 & 1 \\
\hline デフテロイド & 菌 & 2 & 2 & 0 & 0 \\
\hline レットゲレー & $\overline{7}$ & 2 & 1 & 0 & 1 \\
\hline コリネバクテリウ & 么 & 1 & 0 & 0 & 1 \\
\hline 系瑟 & 菌 & 1 & 0 & 0 & 1 \\
\hline
\end{tabular}

ジフテリフ菌，肺炎双球菌，ムコーズス菌，ミタニコッ

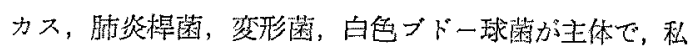
洪つ例の如き緑膿菌とプドー球菌が大部分を占めるとい

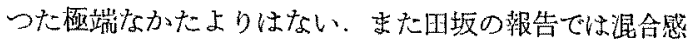
染が症例の $67 \%$ を占めているが，私共の成縝で僅に

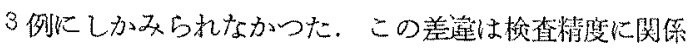
して就るのかるてれぬ。

抗生物質に対する菌の感受性をみてみると（表 1),

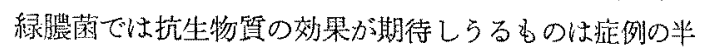
数に満たず，残りは完全な酎性菌である。ブドー球菌 では完全耐性菌は 52 株中 6 式で覑段は $10 \%$ 強に過ぎな い.

かくの如く完全耐性菌による中耳炎症がしばしぱ見出 されることは，術渚として看過し得ないところで，耐性:

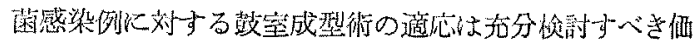
值がある。

\section{II 型心 III 型の適応}

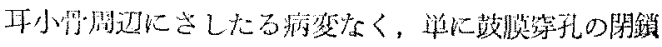
でことたりる埸合は唼獏形成といらべきなので，今回の

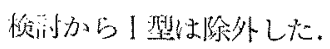

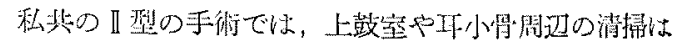
主として搪大 atticotomy によるが，この際アントルム

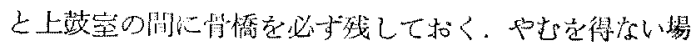

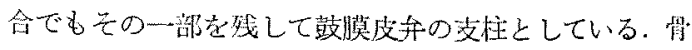
橋を完全に除去しなければ上歎室の処理ができないよ

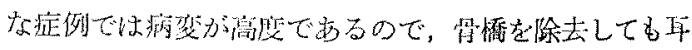
小骨周辺の清琭は徹底しないので，この際悬橋はそのま まとする代りに砧骨を除去して malleolostapediopexy 艺行らことにしている。骨橋を除去しても砧骨が存在少 
硍り病变の処理は困難で，むしろ骨橋老残して砧骨差 除去した方が炎定の処理は微底与る。

领討の都合上，\|型の項には耳小骨尰鎖修愎を行つた ものは除外した。術後聴力の判定は気導純音㯖力損失の 会話音平均值で行い，(500 cps $+2 \times 1,000 \mathrm{cps}+2,000 \mathrm{cps})$

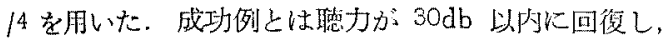

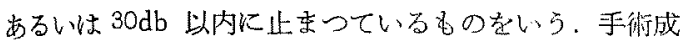
嚗は前半期上り後半期に向上を子たのが多い。

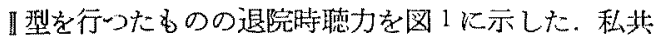
は手術の重点の第 1 を炎症の制御に和いているので,耳 漏の有然と菌の抗生物留感受性を重要国子と兄做して， これに基いて手術成績を分類した。

图 1 型の退院腊聘力

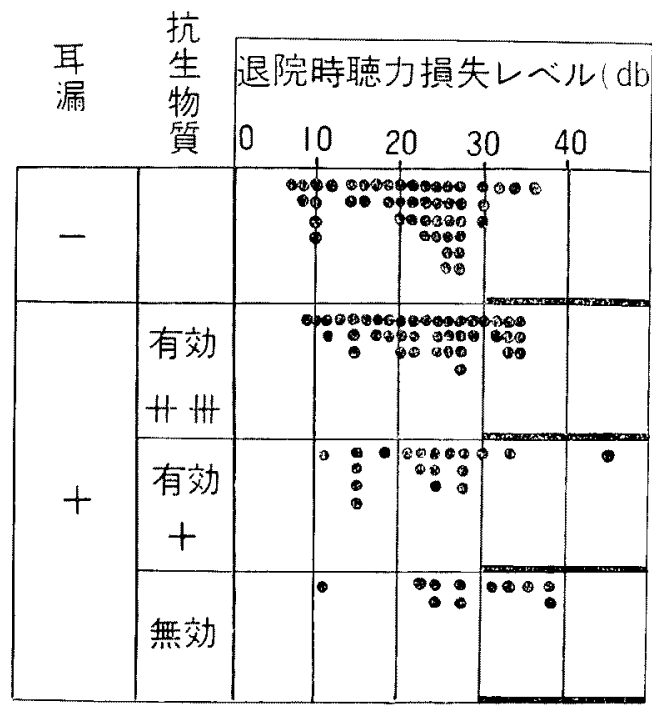

I型の症例世 118 例で，耳庥のないもの46 例中成为

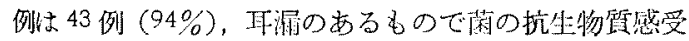

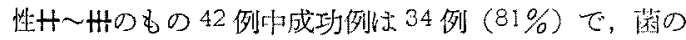
感受性十のもの 19 例帄成功例山17 例 $(90 \%)$ である。 これら3程の症例の手術成結は大きな差異がないが，完

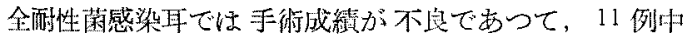
成功例恃 6 例 $(55 \%)$ 飞止变る。

型の適応以上小成續からかなりはつきりしてく

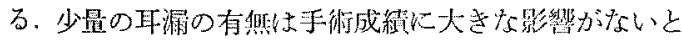

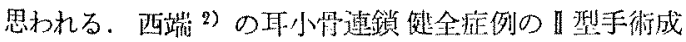

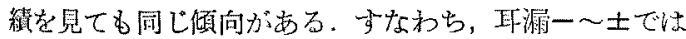

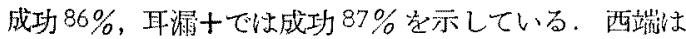

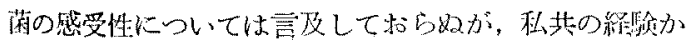

らすると耐性菌感染耳は』型の艮好な適応とはい党な

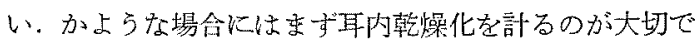
ある。

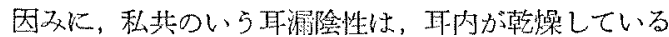
かあるいはやや湴潤してい台程度のbのをいい，耳漏隄 性と以，鼓室に分泌颀が好るが少最で，外耳道には流出 しないむのをいら。外耳道に流机る程度の耳漏学又る症 例士，一论的心繛室成形手術の刘象から除外している。

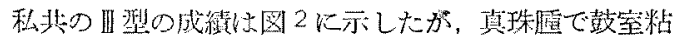

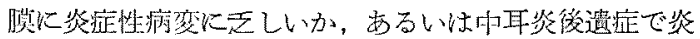

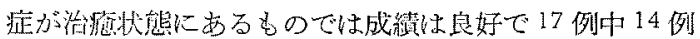
$(82 \%)$ が成功している。 しかし故哣に炎症が相当にあ

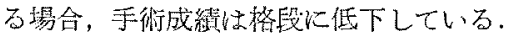

图 2 型の退院時聴力

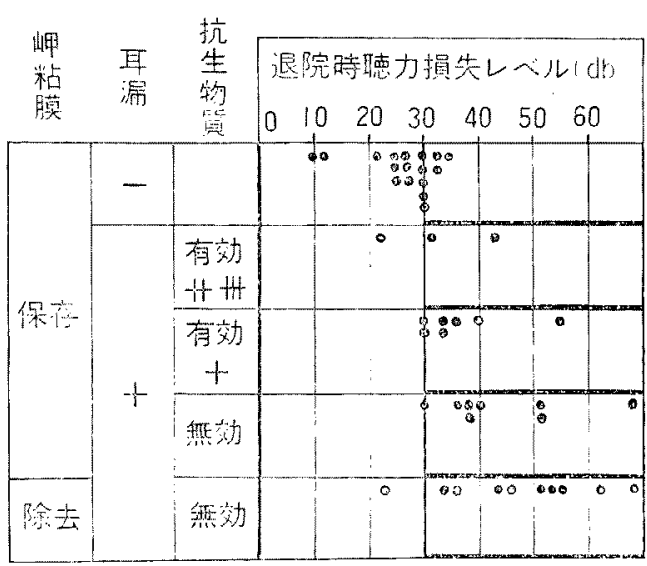

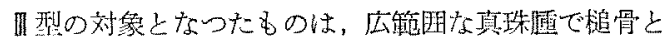

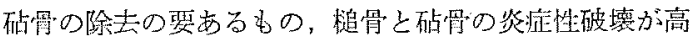

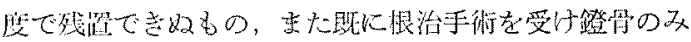

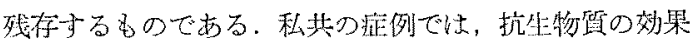

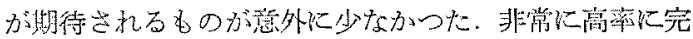

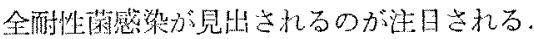

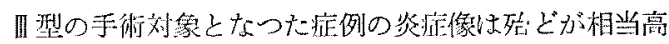

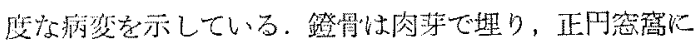

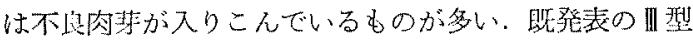

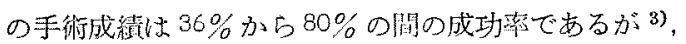

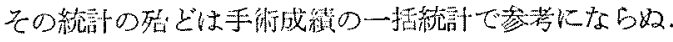

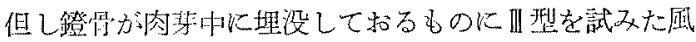

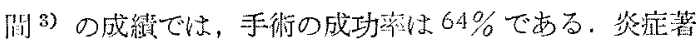

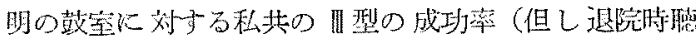
力）经28例中成功 4 例 $(14 \%)$ で，国间の成維比し 
すこぶる不良である．但し退院時聴力は最終的成績でな

く，後日の聴検で聴力が好転することがしばしばある。

\section{耐性菌感染耳の検討}

以上の手術成續は退院時㯖力関してであつた，多く の症例では退院時亄室にはな挆焱症が残存しており，時

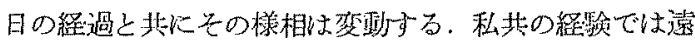
隔成續忧型では大变良好であって，大多数が耳内乾燥 乙聴力は依然として良好である。

四型は『梨に比較して资症の制御にすこがる不利な条

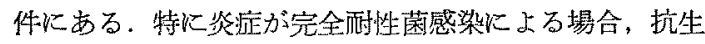
物質による炎症の制圧は期待できない，そこで四型の遠 隔成績を追求して，耐性菌感染耳の手術問題を吟味して みた。後藤々板倉 ${ }^{4)}$ にると，鼓室成形後の聴力は退 院後も变動することがあり，時には1年後に至つてもな を安定しないことがあるという。この点に爁み，今回の 検討症例は術後 1 年 6 月以上経過した bのから撰択し た. 私共の四型の症例はもともと多くないので, 取り上 げ得た症例は 15 例に過ざない

\section{この内訳は}

1. 術前耳䨕なく、鼓室にも炎症のなかつたもの6 例.

2. 耳漏少量あり，菌検查で緑澧菌検出（但乙感受性 菌）されて唟つたもの1 例.

3. 完全酎性薄感染例 8 例.

となつて㧍る。

第 1 の6 例は，その内 5 例方真珠腄，1例が根治手術 後の症例で，遠滆成續はすべて良好である，聴力はいず

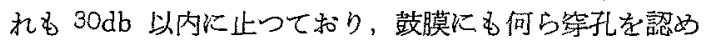
ず完全漧賟している.

第 2 の 1 例は，退院時聴力が $22 \mathrm{db}$ であつたが， 3 年 後の今日でも低然としてこのレベルに止り，耳内は完全 に乾燥している。

第 1 ，第 2 の各症例から，退院時聴力が 良好なら這隔 成線も充分期待できることが示唆されるが，完全耐性菌 感染例ではこの点如何であるらか. 第 3 の完全耐性菌 8

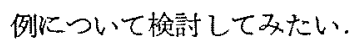

酎性菌症例 1 (図 3):

本症例は以前両耳根治手術くるも耳漏停止せず，私共 が両耳の III型手術を行つたものである，術前の菌検查で は緑膿菌が見出されておった。

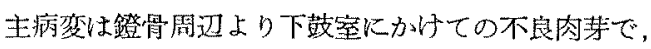
極力これらを除去した．岬战膜の病変は此較的軽度なの でこれを残置している.

退院時聴力は右耳 $35 \mathrm{db}$ ，左耳 $30 \mathrm{db}$ であるが，4 年
图 3 症 例 1

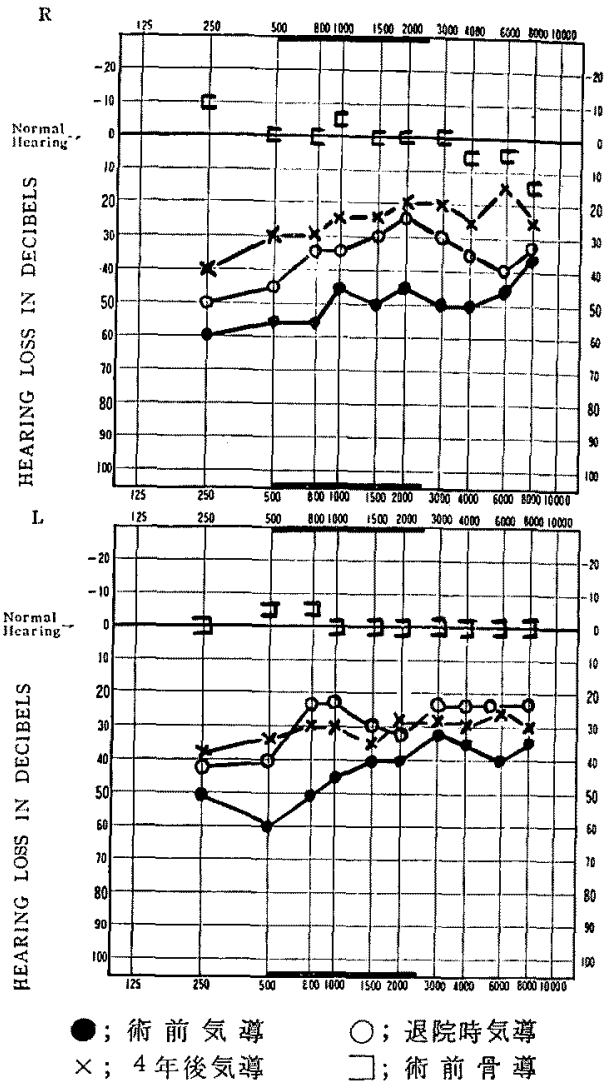

图 4 症例 2

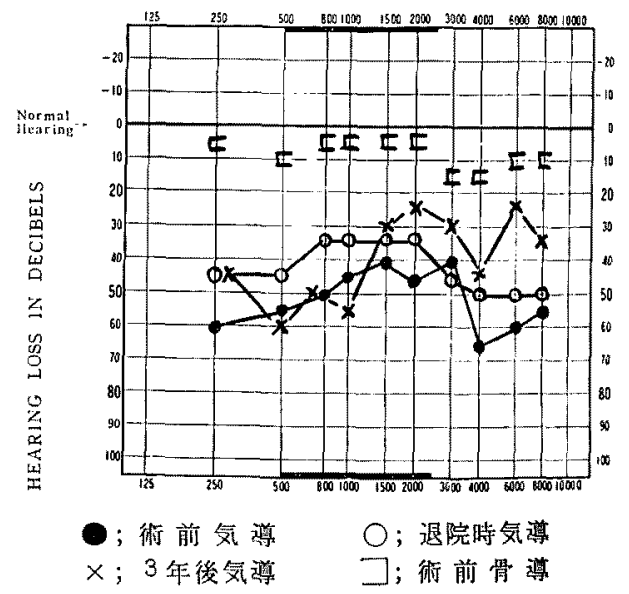


後では右耳 $30 \mathrm{db}$ ，左耳 $34 \mathrm{db}$ となつておる，耳内は完 全に乾燥し鼓膜に穿孔を見ない，

酷性篦症例 2(図 4):

術前の菌検查で緑膿菌が見出されて扣つた．鼓室病変 はすこぶる高度で，鐙骨から下鼓室にかけ不良肉莱多 く，岬粘膜は肥厚は中等畑であつた。諆粘膜を保存して 一次的に西型手術を行つた。

この例の退院時㯖力は $35 \mathrm{db} て ゙ ， 3$ 年後の聴力は 49 $\mathrm{db}$ K低下している。但し 3 年後の耳内は鼓膜に小驾孔 を㒛めるが，耳内は完全に乾懆しておる。

以上の症例の1と2 を比較すると，鼓室病変が強い場 合に敬室粘膜を保存することはよくないように思われ る.墥室粘膜の除去は炎症処理の徹底を期する上には望 ましいが，その反面炎症性肉莱の発生はさけ難く，耐性 菌感染のある場合にはその制圧が仲々困難である。

この問題の検討のため，両耳とも完全耐性菌感染があ る同一患者で両耳とも血型を行い，この際一側では墥室

图 5 症 例 3

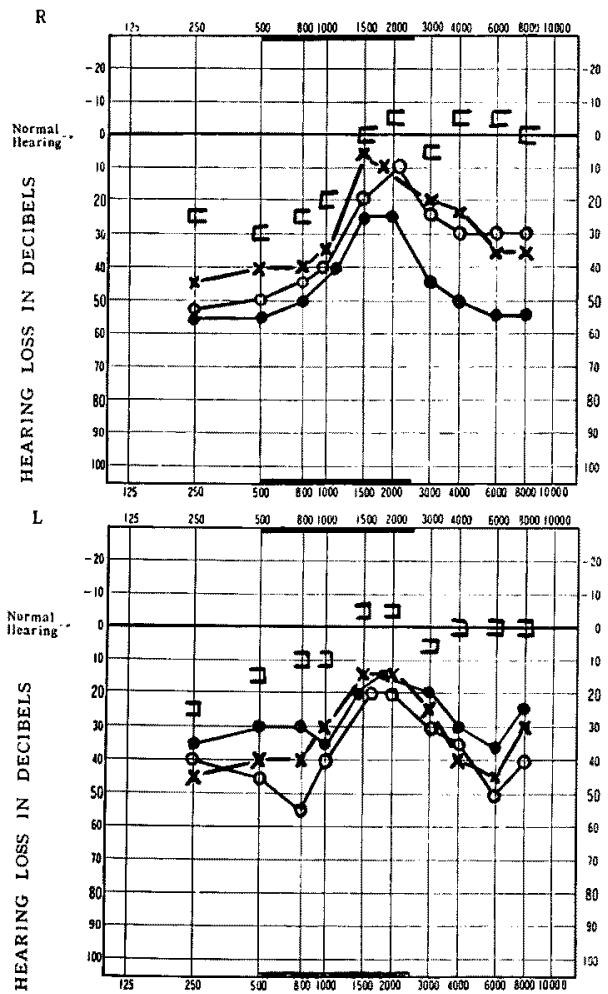
; 術前気 道
○; 退院時気導
×；2 年後気導
]; 術前骨筫

粘膜を保存し，他側で恀これを完全除去したものに注目

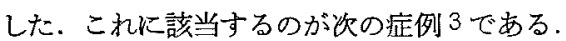

面栍菌症例 3 (図 5):

兩耳共以前根治手術を受けて招るが完全乾懆するに至 らず，両耳より緑膘菌が検出され，乙かもあらゆる抗生 物質に対し完全に耐性であなた。

手術所見は左在殆ど同一で，岬粘膜の肥厚は軽及乃至 中等度である，右耳では鼓室粘膜を完全除士，左耳では これを保存した。

退院時聴力は右耳が $36 \mathrm{db}$ ，左耳が $34 \mathrm{db}$ で聴力は良 好でなからたが，2年後には右耳性 $30 \mathrm{db}$ ，左耳は $28 \mathrm{db}$ となつて括り聴力は良好となつた。 な怙耳内所見は，右 耳に鼓膜に小穿孔，左耳には穿孔がなく，両耳とも耳内 は完全に乾燥していた。

風間 3) は吱室粘膜の 微底的除志を主張しているか゚， これに反し咕室粘膜はなるべく保存するといら意見も強 いしかし本中例に関する限り，鼓室粘膜を徹底的に除 去しても，战莫を保存したものと成績に 雾少はなかつ た，敖室粘膜を残すか除去するかに画一的な考えをする 必要はないように思える。

耐性菌症例 4,5,6 (図6):

ここに述べる 3 症例はいずれも既に根治手術を受けて おり，術後も耳内乾燥せず，耳漏中の菌はす心て抗性物 質に対し完全に耐性を示していた。

手術所見では，い-゙゙れも鼓室の病変は高度で，鐙骨周

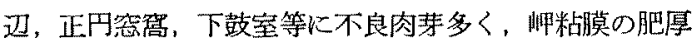
は高度であつた。3症例とも鼓室粘膜を除去して微底的 清掃を行つている。

症例 4 では，退院時㯖力は $54 \mathrm{db}$ で，1年半後には聴 力は $50 \mathrm{db}$ である.1 年半後に至るも鼓膜には穿孔をみ ない.

症例 5 では，退院時聴力は $44 \mathrm{db} て ゙ ， 2$ 年後には 35 $\mathrm{db}$ となつている。現在迄耳内は完全に乾喿して抢り， 䩳膜には穿孔を認めない。

症例6では，退院時聴力は 61db で術前より慗化して いるが， 2 年半後には聴力は $45 \mathrm{db}$ 迄回復していた。こ の例では鼓膜に中等大の穿孔が形成され，耳漏はないが 中耳显潤して㧊つた。

従来の II 型の手術統計では，完全耐性菌感染について 取扱のて扣らないので，私共の参考になる頯料に之し い.それで今回の少数例に基いて想像をしてみる. 完全 耐性菌感染耳に豉室成形術（而型）を行うと，耳内の乾 燥化とい5点では成繢は意外に良好である，しかし聴力 
图 6 左より症例 4,5 及び 6

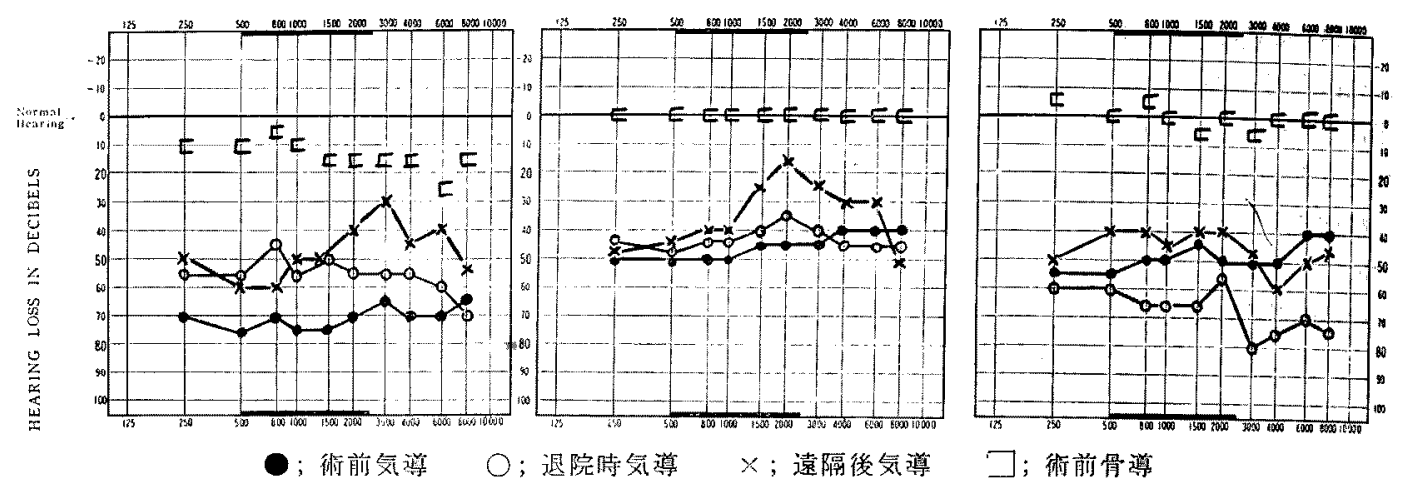

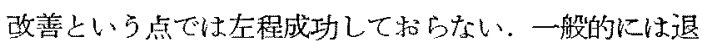

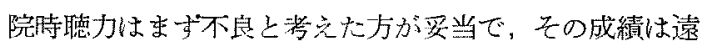
原成績で判定しなけ柇ばなら奴。

完全耐性菌感染の 形型 8 症例 (患者数6人) の結果で

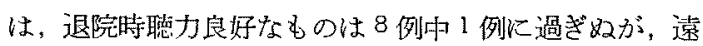
隔成績では聴力良好例は8例中3例上なつている。

私共の不成功例の大部分は病变高㧔なるのであつたこ とからして, 炎症，特に正空窩の病変の清掃不完全な ことが失敗の原因ではないかと思孙わが，ま大鐙骨周 辺に含気腔を形成するに失敗した可能性も考えられる。

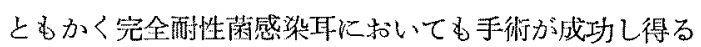

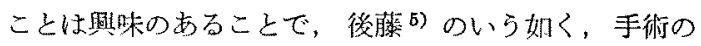
成功率は衔者の技術が非常に大きな因子である。技術の 未熟を抗生物貿等で補足して可たれり上すべきではな w.

\section{伝音機構の修複}

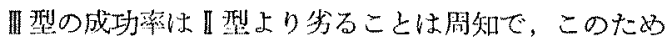

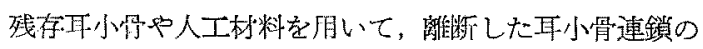

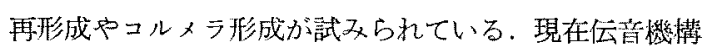
の修復に用いられている主な材料を一括して表2に示し た。

耳手術に人口材料を湖明するのに賸否雨論がある。

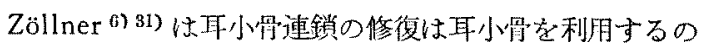
がよく，人工材料を用いるとあとで排出され易い，をた 遊離学を耳内に入れると肉莱の発生を惹起し，骨の変形 や瘉程等が文られるといつている. Farrior 11) 同意 見で，異物を用いると鼓室の炎症が再然するし，遊傩骨 を用いると線維性又心骨性㾇着が捄さると述べている。 㚞本 ${ }^{14}$ ) による亡, 绅症のある場合異物の使朋は望まし くない.

賛成論者もかなり多い, Harrison ${ }^{32)}$ はタンタラムワ
表 2 伝音機㭗修復の主なる材料

\begin{tabular}{|c|c|}
\hline 材 & 表 \\
\hline 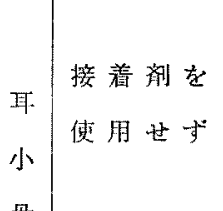 & 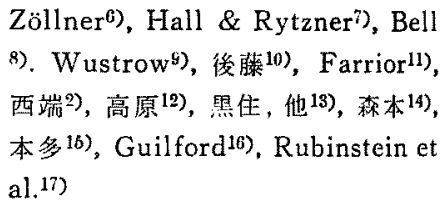 \\
\hline $\begin{array}{l}セ x \text { ソト } \\
\text { ダッタペルカ }\end{array}$ & 風間3) \\
\hline bone glue & Sataloff ${ }^{18)}$ \\
\hline 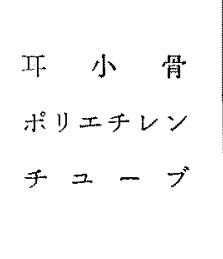 & 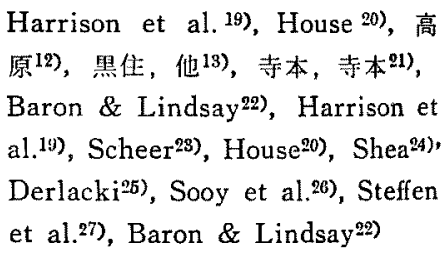 \\
\hline $\begin{array}{l}\text { 小 骨 } \\
\text { ステンレス } \\
\text { ワイヤ一 }\end{array}$ & $\begin{array}{l}\text { Farrior }{ }^{11)}, \text { Schukneoht \& Oleksi- } \\
\mathrm{uk}^{28} \text { - }\end{array}$ \\
\hline 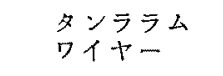 & $\begin{array}{l}\text { Harrison et al.19), Schnknecht \& } \\
\text { Oleksiuk }{ }^{28}\end{array}$ \\
\hline 金 & Ehmke ${ }^{29)}$ \\
\hline Kiel bone & Raymond-Jones ${ }^{30)}$ \\
\hline 学 皮 質 & 四端2) \\
\hline
\end{tabular}

イヤーを鼓空に用いると，翼常な組織反応がおこつて周 包と療着が抏こるか゚，ポリェチレンを用いると㽬室粘膜 の反応は非常に軽度であつたといつている. House ${ }^{83)}$ は350耳にポリエチレンをコルィラとして网いたとこ ろ，翼物反応を扣こすことなくよい成績を得ている。 Lindsay 34)(ホポリエチレンをコルォラに用いた忠者の死 
图 7 砧錗関節接着の成維

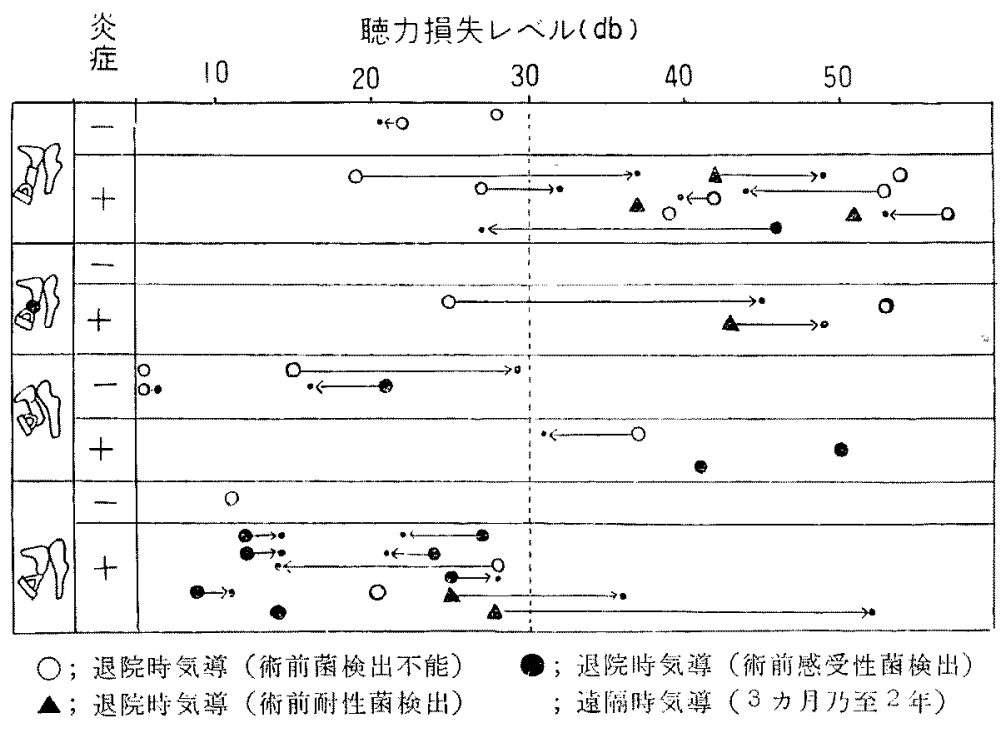

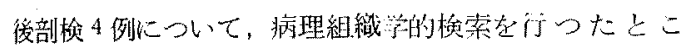
ろ、ホリエチレンは㱠ど豎物反志を括こして扰らない を認めている。

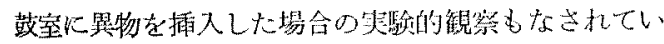
る. Harris ${ }^{35)}$ は猫の政室にポリエチンンを捙入した

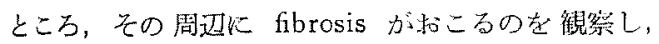

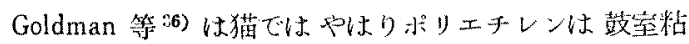
膜に相当著明な組織反応を索扣こさせるが，チフロンを䏸 いるとかよらな反応は極的て軽庭に止ると裂告してい る、ラッテを用いた Hohman 等 67) の観察では，ポリ エチレンを㺃室に㧴入すると粘膜に反応が強く扎こり， ポリエチレンの周辺に肉菁組織が発生してこの中に異物 巨緗胞が出現するのを訕明している。

辝室成形術に対する異物使用の可否忧，鼓室粘膜の炎 症の有然とも関連して諭ぜらるべきで，私共の推測する ところでは，否定論者は炎症性病変のある場合には異物 使用は不可というものの如くであり，筫成諭者の場合は 炎症性病变のない症例を根拠火して論述して扣るるのの 如くである。動物垁験による成續は人間の場合之同一で なく，生物の種属差によつて成續は変動するの で，故室に翼物使用の可否の結着はあくぬで臨 㕅観察によらねばならない。

回型手術で每常良好な術後隈力を確保するの は容易でない，特に炎症の存在する证例ではこ の感が深い，正型が型に比べ手術成縝の不良

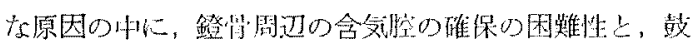

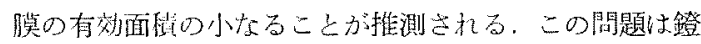

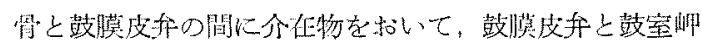

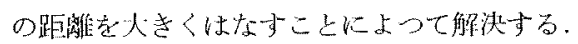

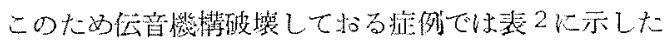

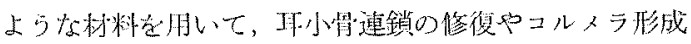

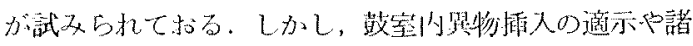

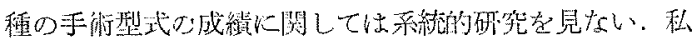

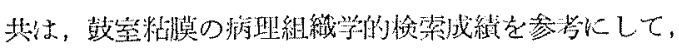

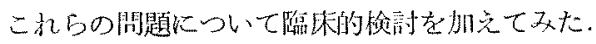
砧鐙答接合とその成績 :

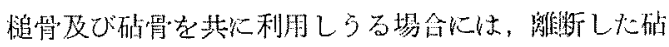

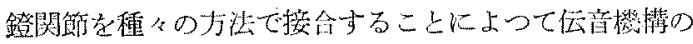

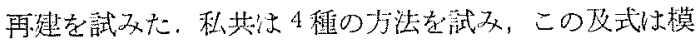
式的に图７に示した。これを四の順字で遮べると以下の 如くである。

1. 砧骨器脚にポリェチレソチニーブをはめ，チユー

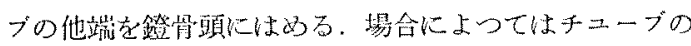
中央に切れ目を入れてチュープを曲げ，これによつて砧

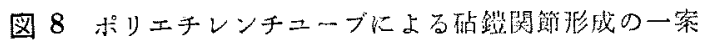
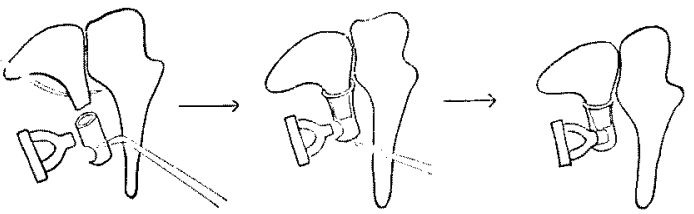
骨々鐙骨の接合を容易ならしめる。むし鐙骨頭部消失し ておるならぱ，チユーブを crus の基部垱る上らにす る。か上らな方法捉来の諸報告に散見与るものであ る.

2. 砧骨長脚を鐙骨頭部にのせ，両者を接着剂で接合 する，使用した接着剂は吉富製楽提共の “Biobond” で，本品は通常は液状であるが，水分にあうと急速に硬 化する性質をるつ有機高分子化合物である。

3. ポリエチレンチューブを用いる万法であるが，砧 骨と鐙骨の軏絡方法に私共独自の工夫をこらしたもので ある。

適宣の長ざのポリエチレンチニーブの一端代近く，丁 度鐙骨頭部がはぬるだけの穴を作製する。これによる砧 骨と鐙骨の接合要領は图8示したが，チューブが小さい ので摃子では取报うことができない，

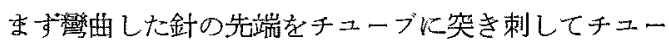
ブを保持する。つい゙ゅるく粼曲した別の針で砧骨長脚 を持ち上げつつ，チューブの他端を長脚に挿入し，チユ ープに作つた穴が鐙骨頭部の位置にくるように充分樑く 和し入れる、最後に針で砧骨長脚を支えつつチニープの 穴に鐙骨頭部を挿入する。

4. incudostapediopexy が第4の方法で，砧骨と槌 骨を下方に引さきげ，砧骨長脚を鐙骨頭部に 接着させ る。この場合，雨者を自然のままられさせるだけで特別 な処犆は講じない。

以上の方法による手術成績は図７にをとめて ある、結論的にいらと，いささかでも跂室に炎 症があるすのにポリエチレンや接着剂を用いる と成績はよくない，かりに退院時聴力がよい上 弓見光ても，遠隔成績は殆ど失敗する。こ礼化 反し，炎症のない症例ではポリエチレンの使用 は許される。

結局，炎症のある症例では第4 の方法が推賞 され，その手衍成績をみても信賴性が高い，砧 骨と鐙骨をふれさせたものには術後真の関節が 再形成されるのでなく，結合織性の連結に止ま

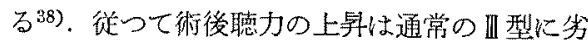
ると想像される.この点で與味のもたれるのが 第了の方洗で，この方法でうまくやるとポリエ チレンチユーブが鐙骨にしつかりはまるので， この方法が聴力のより高度の上昇を望みうる。 事实，殆ど正常德力に回復した泟例が得られ た.
コルメラ形成とその成績：

耳小骨連鎖離断症例で桘骨と砧骨の両者が利用できな い場合，正型手術を行わないとすると，残存耳小骨ある いはとの他の材料を用いて䞚膜皮弁と蹬骨の間にコルメ ラを置いて，皮弁と鼓室岬の距雄を大にする力法がとら れる。

私共の試みた術式は図9に示寸如くで，図の順序に述 べると以下の如くである. 残存耳小骨を利用する際, 私 其は䊚骨のみを用いることにして沏り，砧骨を利用する ことは決してない（この理由は後述する).

1. 鐙骨の久残存する場合には主としてポリェチレン チユーブをコルメラとして用いる。若干の症例には婎離 自家骨を試用した。

2. 䄱骨柄にポリエチレンチユーブをはめ, チューブ の他端を鐙骨を当てる.

3. 桘骨柄を鐙骨の上炕き，両者を接着剂 (Biobond) に上つて接合する.

4. malleolstapediopexy が第 4 の方法で, 単に棺骨 柄を鐙骨にのせただけである。

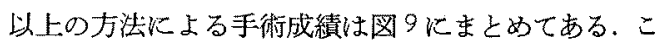
こでもはつきりいえることは，炎症のある鼓室にポリェ チレンや接着削等の異物を插入するのは禁忌で，退院時 㯖力をみても殆ど不良である，若干の症例では退院時聴 力が良好なものがあるが，しかしその遠隔成績は不良で 例厄聴力低下が招こつている。

図 $9 コ ル メ ラ$ 形成法の成績

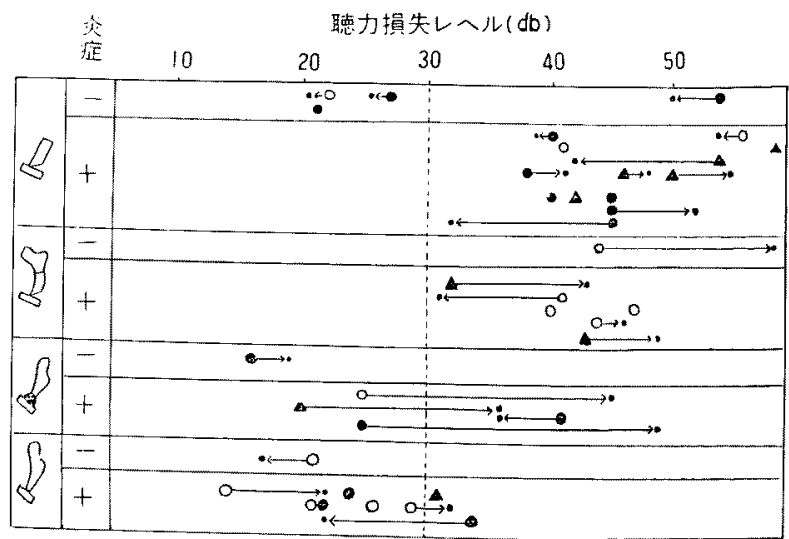

○; 退院時気遒(街前菌检出不能)

- ; 退院時気溥（街前感受性菌梌出）

A; 退院時気尊（術前耐性菌検出）

；虺隔時気導 ( 3 力月乃至 2 力年) 
結局，桘骨を利用し得る場合にはこれを用いて第 4 の 方法で手術を行らのが望ましい。この手術は鼓室に炎症 のあるものにも適用ができ, 手術成績にも信頼性が括か れる. 本術で期待しらる術後聴力は 20〜30db の辺と思 5.

鼓室に炎症がない場合でも桘骨を利用するのが望まし い.かような場合桘骨を除去して人工材料でコルメラ形 成を行うことが許されるが，人工材料によるコルメラで も期待聴力はやはり 20～30 db 位と思われるので，人工 コルメラに特別な利点が認められないからである.

\section{異物使用之耳小骨処理の問題について}

異物使用症例の再:手術所見:

今迄の成績では，炎症のある鼓室に異物を插入するの は禁己で，異物の使用が許されるのは鼓室に炎症の全く ないものに限られていた，従来の異物使用例の臨床報告 は乏しく，鼓室成形術を対象とした病理組織学的検索成 績は殆ど発表されておらない，私共は異物使用例で再手 術を行つたものについて所見を述べてみたい.

異物症例 1 (長○川○平, 男, 26 才).

昭和 37 年 5 月某医により両耳の嗢室成形術を受けた. しかし両耳共聴力の 改善を全くみないので, 昭和 39 年 11 月に再手術を行つた.

前回の手術記録によると, 左耳では鼓室の炎症は全く なく，桘骨を除去して砧骨と鐙骨をポリエチレンチニー ブで連絡した．右耳では鼓室に軽度の炎症があり粘膜は 整度に肥厚してお゙つたが，肉芽は全く認めていない，砧 鐙関節の離断があつたので，砧骨と鐙骨をよせ，両者を 私共と同一の接着剤で結合した.

左耳の再手術所見では, 鼓室の炎症は全くなく糊莫は 全く正常で，肉芽の発生は全く認められない. 前回挿入 したポリェチレンチューブは鐙骨より離れて転位してい るが，他端は砧骨長脚に插入されていた，橋部を落し， 砧骨とポリエチレンチユーブを除去して四型とした，退 院時聴力は $28 \mathrm{db}$ であつた.

この例では, 炎症のない鼓室ではポリェチレンチユー ブは何らの異常組織反応を㧊こすとなしに，長時日存在 できるとを示しており，この意味で貴重な1例であつ た.

右耳の両手術所見では，耳小骨，特に砧骨之鐙骨周辺 に著明な肉芽発生を認め, 前回の手術所見では肉芽を全 く認めなかつたのと比べてすこぶる対照的である. 右耳 では橋部は保存し肉芽を清掃の上砧骨と鐙骨をそのまま 接触させた incudostapediopexy を行つた，退院時聴
図 10 症例 1 (長 $\bigcirc 川 \bigcirc$ 平); 接着敦使用 後の買物巨細胞 (矢印)

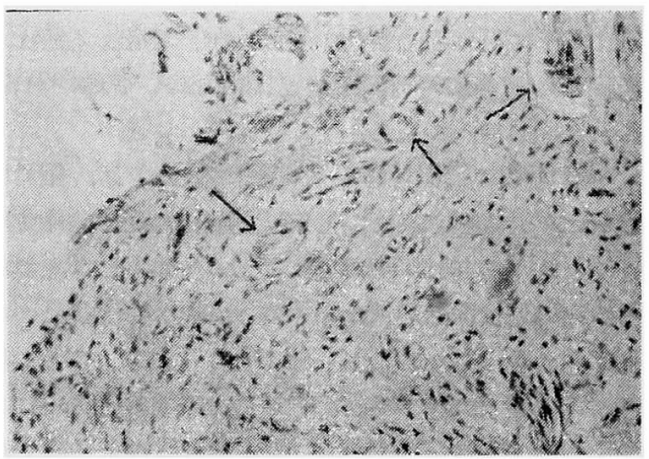

力は $26 \mathrm{db}$ である.

右耳の再手術に採取した肉若の病理組織像は図 10 の 如くで, 多数の異物巨細胞の出現が注目される. 摭大像 では, 巨細胞内には無構造でよく光を屈折する半透明な 固体が封入されている.このものは前回の手術に使用さ れた接着版の破片と考古られる。

要するに, 炎症のある鼓室に接着凪を使用すると, 鼓 室粘膜が異常反応を抽こし肉芽の 発生をみるよらにな る. 本例では接着風による鼓室の 異物性反応を示した が, ポリエチレンによる類似の反応は異物症例 2 で観察 された。

異物症例 2 (吉○恵○, 女, 10 才).

昭和 39 年 7 月に右耳の鼓室成形術を行つた。砧鐙関 節の離断と粘膜肥厚が主な所見で，鐙骨周辺や砧骨長脚 には肉芽は全くなたつた。炎症のある鼓室にポリエチレ ンチユーブを㨉入した際の所見を求める目的で第一回の 手術を行つたが，砧骨と鐙骨の連結は既述の第 3 法で行 つた．但しポリエチレンチューブを除去する增合に備兄 て，鐙骨頭部がチューブにゆるく插入されるように注意 した。

術後 10 日の聴検では聴力不良であつたので再手術を 施行した.この所見では，砧鐙関節附近に大量の肉芽が 発生し，このためチユーブは鐙骨より離れて遥か前外方 に転位して和つた。

再手術によりポリエチレンチユーブを除去し，耳小骨 周辺の清掃を行つて 砧骨を鐙骨頭部にのせて incudostapediopexy を行つた. 退院時聴力は 30db に達しなか つたが、3ケ月後には聴力好転し $25 \mathrm{db}$ となつた.

次の症例は, 炎症のある鼓室に遊離自家骨を插入して した实験例である，自家骨でも遊離したものは異物とな 
ることが示されている.

異物症例3 (長○川○子, 女, 22 才).

以前某医により根治手術を受けたが，難憄を主訴とし て来院した，来院時耳漏は殆ど恋めない，炤和 39 年 3 月に鼓室成形術を行つた。

手術所見では，槌骨と砧骨は既に除去され，鐙骨は foot plate の及残されていた．鼓室粘漠の肥厚は中等度 なのでこれを保存し，卵円空にはごく少量の肉军を認め るのみなので操作は加党なかつた。

側頭骨の骨は質から遊崔した小骨片を作り，これを卵 円空の上に立てコルメラとし，その上に耳後部より得た 皮升を張り鼓膜を作成した。術後聴力改善を久ないの で，14日目に再手術を行つた。

再手術所見では，卵円空周辺に大量の肉芽が発生し， 移植骨片はこの中に埋れていた，肉芽を除志してN型と したが，退院時聴力は $34 \mathrm{db}$ であつた．肉莱の病理組織 学的所見は図 11 の如くで，罢物巨細胞の出現が認めら れた，巨細胞の拨大像では，䧹骨片と思われるものが細

図 11 症例 3 (長○川○于); 骨片插入による 異物細胞（矢印）

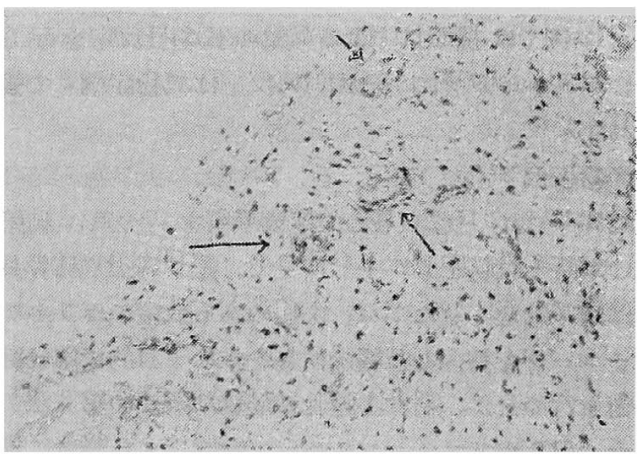

图 12 症例 4（広○莪○）；骨片抑人による 異物巨稩胞 (矢印)

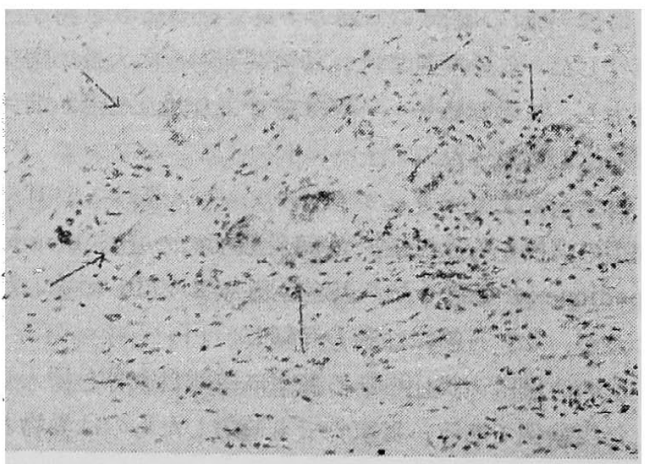

胞内にとり入れられているのが見えた.

異物症例 4 (広○義○, 男, 43 才).

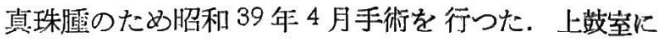
多量の真珠腦があつたので缒骨と砧骨を除去して I 型と した．鼓宝粘膜の軽度の肥厚がみられるので，鐙骨周辺 には肉来を認めない。

側頭骨より得た遊離骨片を試みに答骨に接して鼓室に 移植した，術後 11 日目に鼓室を点検したところ，鐙骨 周辺に大量の肉芽が発生して招つた。 この肉芽の病理組 織学的検索所見では，やはり多数の炎物巨細胞が認めら れた（図 12）。

以上の絟駼によつて，自家骨といえど遊離骨片を炎症 のある鼓室に移㥀すると，その骨片は薣室粘膜に対し異 物として作用するとい兑る。この結果はまた Zöllner6) 31) F Farrior ${ }^{11)}$ のいらところと一致する.

耳小骨心処理 :

自家骨といえども遊離骨片となると，炎症のある敋室 に異物反応を怙こすが，この事実は重大な示唆を含んで

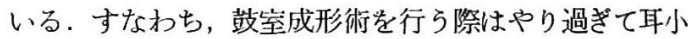
骨えの栄養血管を切断したり，耳小骨の粘膜を完全に除 去した場合には，耳小骬は事実上遊離骨となる。る乙鼓 室に炎症があれば遊離耳小骨による買物反応が 括こつ て，鼓室に肉芽の発生を萡起して 聴力に悪影響を及ぼ すそれが故に，鼓室成形術を行う場合には，耳小骨の 血管系の解剖学的知識をもつの゙非常化大切である.

耳小骨血管については Nager \& Nager ${ }^{33)}$ 及び Hamberger \& Wersäll 40) の記述があり，耳小管粘漠血 管と耳小骨の栄養については Anson ${ }^{41)}$ p Lindeman 42）の報告がある. Nager \& Nager によると耳小骨兄 の血管采虫大略図 13 の如くである.

砧骨と桘骨えの血管は前鼓室動脈から分岐し，夫《砧

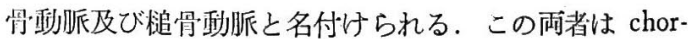

図 13 耳小骨血管系略図

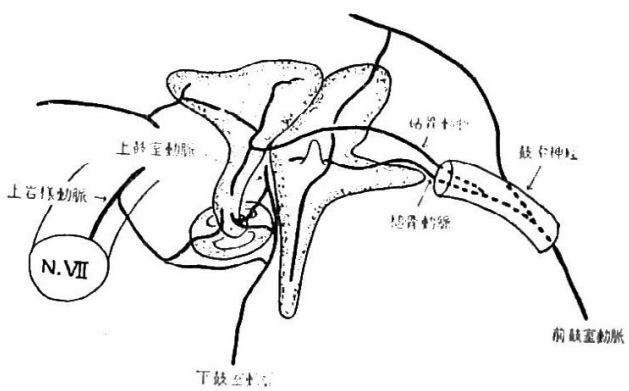


da tympani に接して走り，耳小骨の外側方すなわち豉 瞙側汇まわつて耳小管表面に分布する．楾骨と砧骨に分 布する血管はこの雨血管が主体であるが，図に見る如く この外炕若干の動哌がある。鐙骨に分利する的管は上岩 样勳脈，上及び下鼓室動脈から由来し，その末端は砧鐙 関節を越元て砧骨長脚の下半部に分枯している。

ここに重要なことは，砧骨と桘骨に走る動脈は鼓膜侧 を走るといらことで，この点耳小骨周辺の清掃の際これ ら血管を切㯕しないように注意を要する，また桘骨を除 去才ると，必然的に砧骨動脈务切断され，残置された秥 骨怔血行障害に陌る。私共俚さきに，耳小骨を利用して

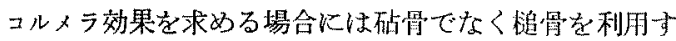
ることを強調したが，砧骨を゙除去しても伯骨に血行障害 が枋こら奴が，榴骨を除去さると砧骨えの血行が不充分 となる理由からである。

もら一つの重要なことは Anson の述べる如く、耳小 骨の栄荃はその表面粘膜より内部に入りこむ血管によつ

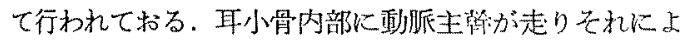
つて骨の栄養が保持されるのではない，このため耳小骨 表面の粘膜を除去し過ぎると，耳小骨の栄㙋障害を括こ してくる，Lindeman 死類似の見解をとつて扮り，鐙 骨手術の後に砧骨長脚の㙹死を見ることがあるのは，砧 鐙関節の粘獏の除去がその原因としている。

ここに执いて，耳小骨周辺の病巣の除志々耳小骨の血 行障害の防止といら互に相反する事象が著起する。か上 5な場合には上鼓室の病変が高度なことが多いので、耳 小骨粘膜の保全にとらわれて不完全な手術を行うょり も，積極的に砧骨を除去して malleolostapediopexy を 行らべを考えている，耳小骨火病変のある場合には多 くは砧骨にみられ，㮩骨の破壊は案外少い，その上砧骨 を除去することによつて上㪗室の清掃は非常に 容易と なり，概骨を残蹎しても清掃の邪曆にならない。

图 14 Chorda tympani 厄上万砧骨固定法

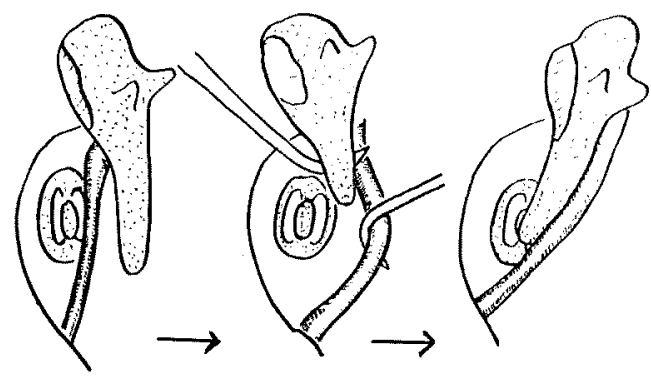

私共つ行つている malleostapediopexy は檤骨柄の先 端を鐙骨にあてる方法であるが，能骨柄を镫骨によせて

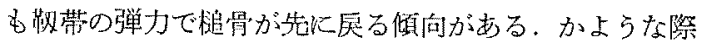
飞は chorda tympani 孝桘骨柄の外僋飞枟位させ，そ

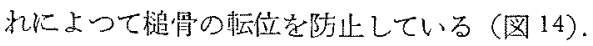

\section{手術諸型の成績の比較}

今迄の顺討で政空成形術について一応の基本的概念 が形成された。しかし malleolostapediopexy あるいは incudostapediopexy などの成綨判定は，比模与べき刘 照が必要である。

異つた急者を用いては成結の判定や比较に不便なの で，同一人の㭧者孛用いて检討した。すなわち，入院期

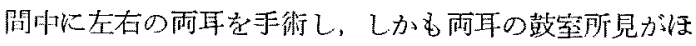
注同一であるが，但し一側の伝音譏構が健全で，他侀の それが離断して淤つたものを撰択した。

この場合一側が II 型で，他側が連鎖修衡型となるが， 【型の手術成績は大变良好なので対照として好通であ

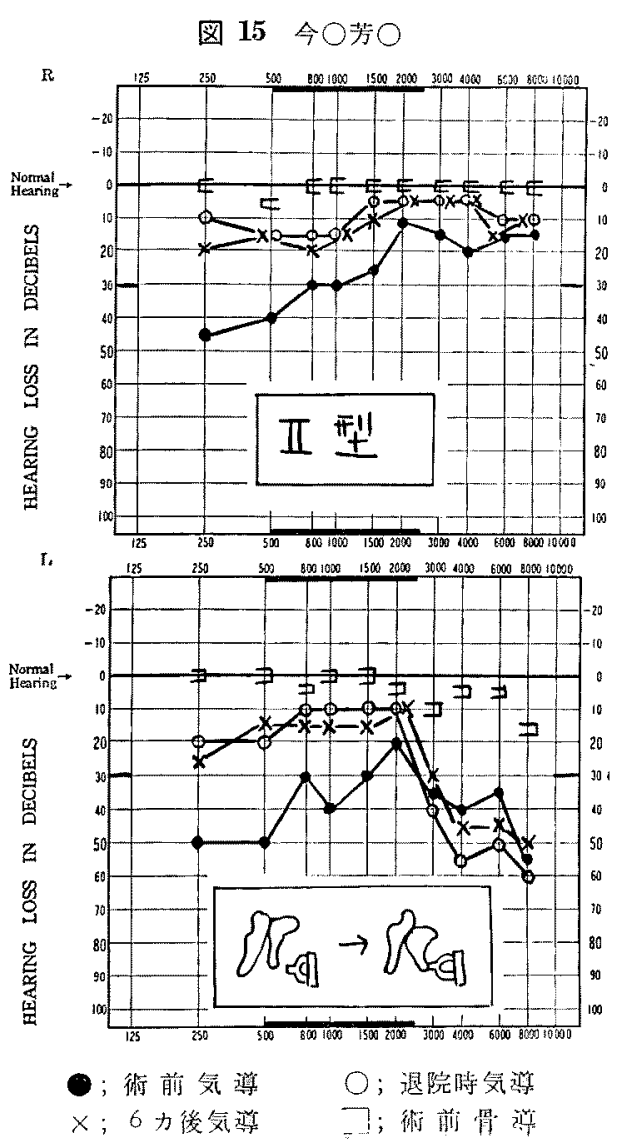


图 16 由于俊门
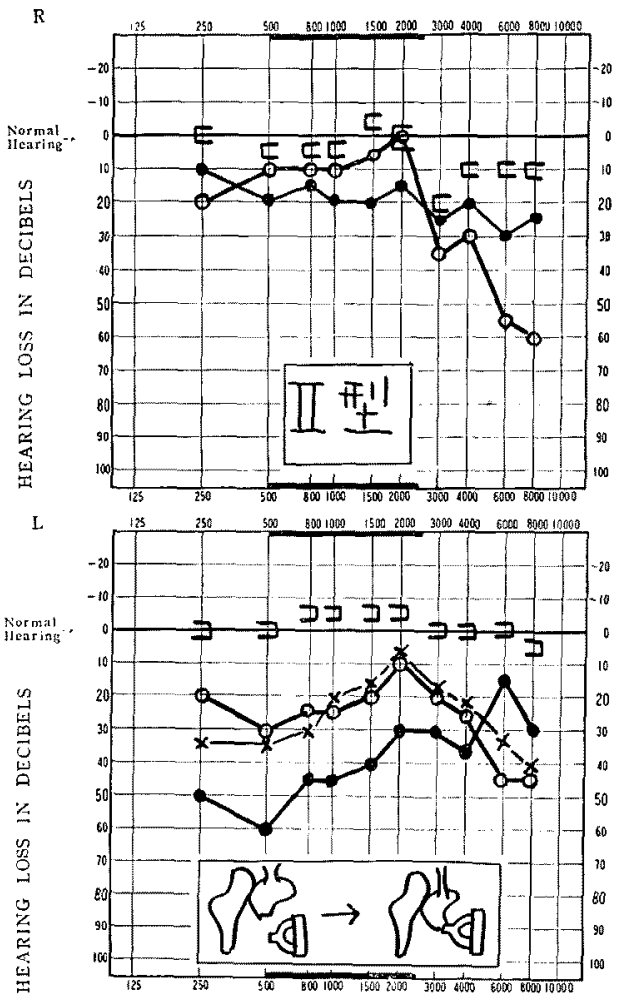

- 0. 马, 415図比同し， $x ; 3$ 力月後気導

図 17 鉿 $\mathrm{O}$ 钽 $\mathrm{O}$

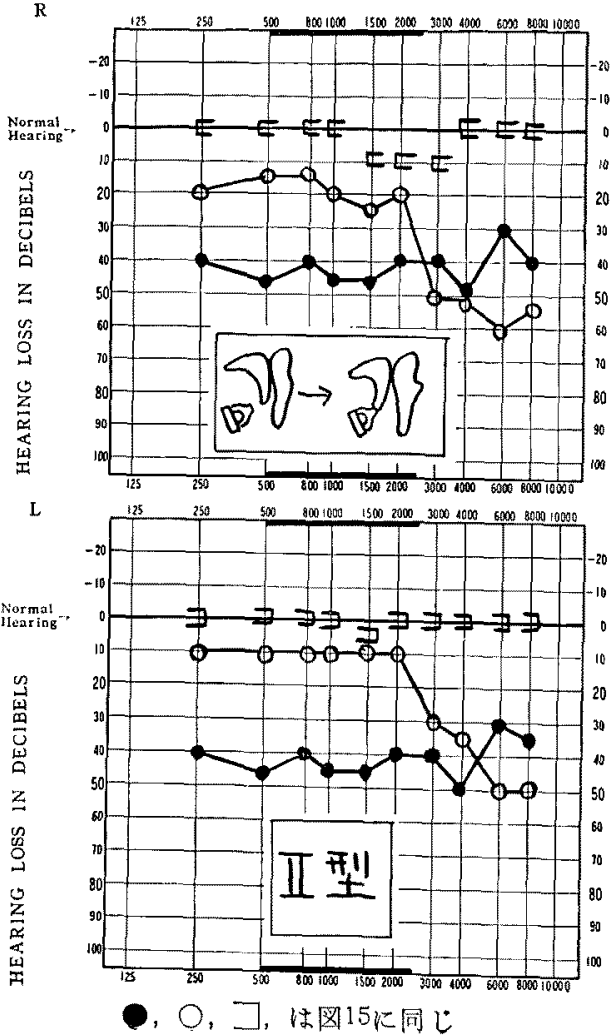

图 18 蒲 $○$ ミ
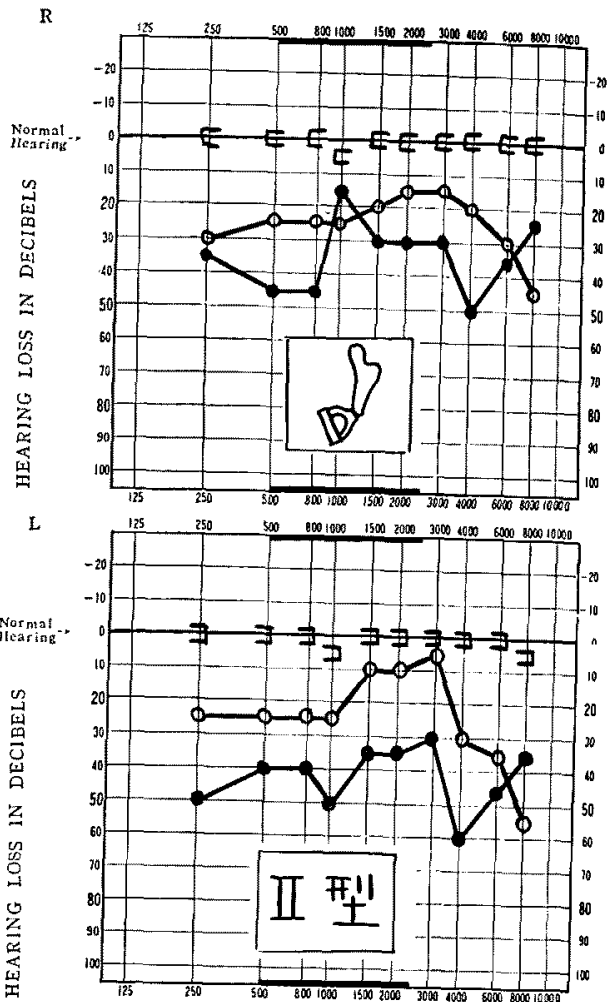

- $， ，]$, 図15亿同し

る.かよらな症例は多くなく4例にすぎぬが（图15〜 18)、これらの症例によると, incudostapediopexy \& malleolostapediopexy む成績は良好で型に 比べさし て劣つていない。

一側に』型手術を行い，他側に異物を利用して䝵鎖修 復型の手術を行つたものは 2 症例ある. 但しこの場合巽 物使用側詰鼓室に炎症の全くないむのである。

円山例（因 19）では，右耳が川型，左耳にポリェキ レンキニーブを使用した，両耳共退院時㯰力は良好であ つたが，遠隔成績をみると右耳の聴力は $26 \mathrm{db}$ ，左耳の それは $31 \mathrm{db}$ となつて秥り，異物使用側の低下が目立 つ.

鼓膜は両耳共小穿孔を形成していたが，耳漏は両耳と も垫めず完全に乾燥していた。

東海林例（図 20）では，右耳が』型，左耳にポリエ チレンチニーブを使用した，両耳共退院時聴力は良好で あつたが，その後聴力やや低下し，遠隔成績では右耳が $30 \mathrm{db}$, 左耳が $37 \mathrm{db}$ となつていた。 
图 19 東○林○久

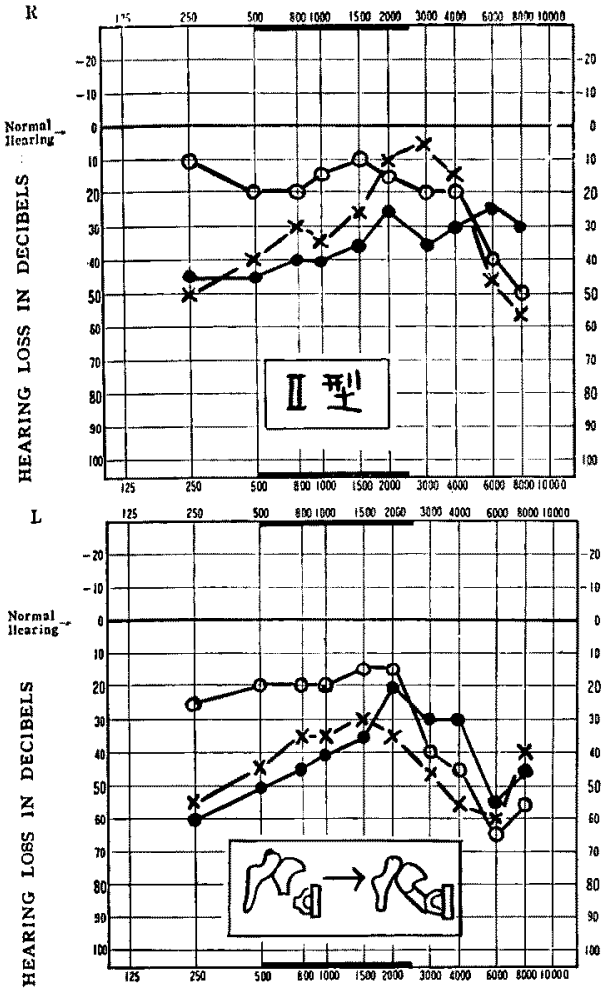

○，O，コ；因15k同し， $\times ； 2$ 年後気導

图 20 円○幸○

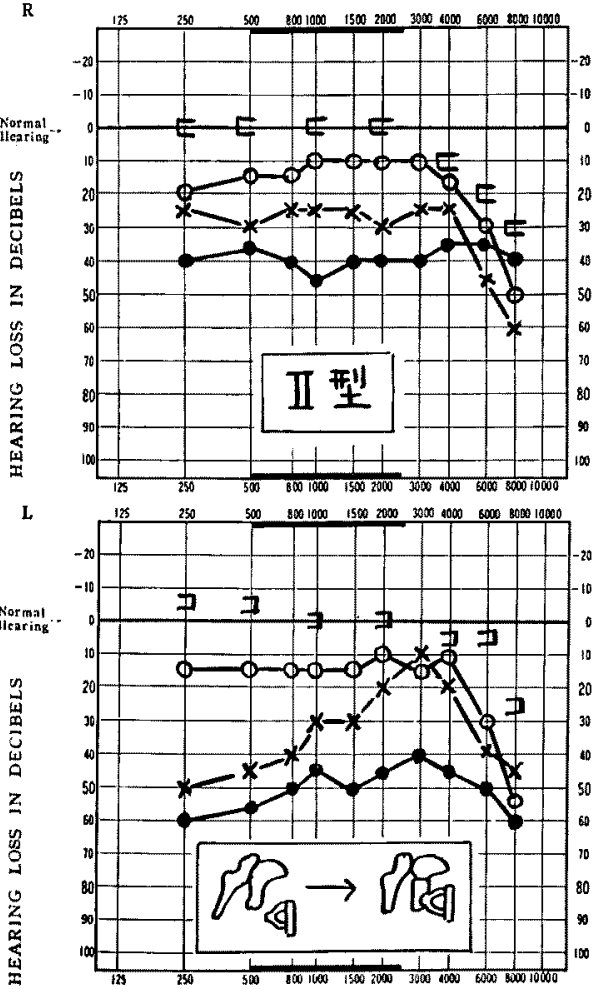

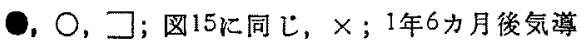

䇅膜は右耳では穿孔はないが，左耳に中等大の乾燥性 穿孔がみられた。

これら 2 症例は敱室内に異物を挿入することに対し警 告を与兄てくれる．鼓室内に资症がない場合には異物の 使用は許されるが，将来聴力低下をきたすような機転が おこつた場合に， I型側の低下に比べ異物使用側の低下 がやや大であると推測される。すなわら，異物を使用す る場合には，鼓室所見ばかりでなく鼻，副鼻腔，咽頭等 の異状の有無をも充分考慮して適応る定めるのが大切之 考える.

\section{IV 型 手 術}

NV 型の手術成績は概して不良といらのが通説である。 私共恃鼓室粘膜を保存したもの，鼓室の粘膜を完全に除 去したるの，鼓室粘膜を除去してそのあとに静脈片を移 植したものの 3 者について手術成績を比較してみみた（図 21).

图 21 N 型の手術成顀

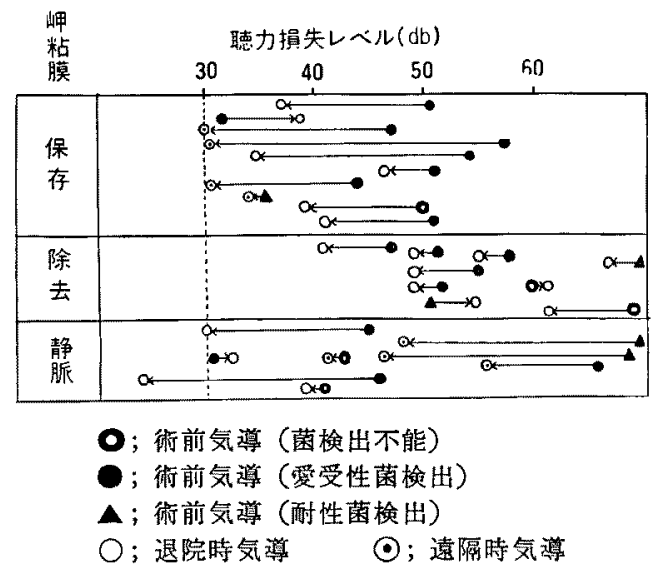

VV 型の一番の問題点は cavum minor の確保であつ て、鼓室粘膜を保存できたるのではこの点有利である. 事実, 鼓室を徹底的に清掃して一次的に植皮したものに 比較して，鼓室粘膜保存の方が成績が良好である。

V型による德力改善には限度があるように思える。す なわち，鼓室粘膜を保存した $V$ 型の私共の成績で蛙，期 待乙うる退院時聴力は 30 40db であるるのの如く，20 $\mathrm{db}$ に近い聴力を得るのは容易ではない上うに思克る。

鼓室の病変が高度で徹底的清掃を要する場合，いきな り一次的に皮弁を植皮するのは禁忌である，まず焱症の 軽快をまつて二次的に植皮する方策をとるべきである。 すなわち，一次的に植皮を行つた場合，図 21 にみる如 


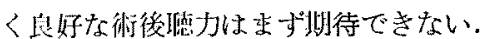

かくの加き鼓点清掃してV型となした埸合には，铬出 骨面からの肉孫発生のため，耳管より下鼓公に沿つて正 円空洋する一連の含氛腔の形成が行和れない，かかる 故に私共は鼓室帅から下鼓室に静脈片を移植して肉茅の 発生の防上效果学狙つてみた。この方法では，目21に 示す如く聴力ががり上景したのは8 例中 4 例で，4 例 中 1 例は $30 \mathrm{db}$, 他の 1 例は $26 \mathrm{db}$ の退院時聴力を示し ている.

静脈片を鼓室に移植した症例を点検した経験では，術 後静脈片はかなり強度の腫脹をきたしており，その表面 は鐙骨頭のレベル位に迄剅隆するよらになるはなた静脈 片の雨側では肉芽の発生がかなり著明なことが多いの で，移植皮弁と静脈片の疮着あるいは肉芽による耳管開 口部の閉塞といつた危险性がある。かような手術では手 術手技の上達のみでなく，应例の撰択いかも成績に関係 すると思秃るので今後も険討してみたいと考えてい 吕。

鼓室粘膜を除去した後，露出骨面を他の組織で被い， 下辝室に含気腔を確保せんとする着想は以前よりあつ た. Frenckner ${ }^{43)}$ は裁室岬に羊膜や骨膜起移植してみ たが，肉莱が発生しやすいのでこれらの組織を用いるの を中止し，現在では專ら煩部粘膜を用いておる，煩部粘 膜を移植して一次的に鼓室を鼓膜皮弁で閐銧すると，移 植粘膜は腫脹 し湿潤してくるので，2 次的に鼓膜を形成 するのをすすめている。

Wullstein ${ }^{44)}$ は，鼓室に羊膜を移植してもすく吸収 されるのでよくなく，また舆粘膜は粘液腺が多くて鼓堂 に移植するに適しないと考克て，口唇糊莫の使用をすす めている、彼はまた静脈片る移植組織として㯖くない が、これを用いる際よはど薄くしておかないと，移植後 腫脹がお゙こり敬膜皮手と接着すると述べている。な和静

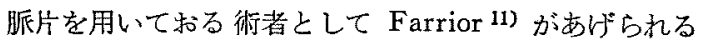

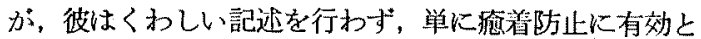
のみいらておるに過ぎない。

私共の行つた N 型の退院時聪力像を図 22 と图 23 K示 した。图22には聴力が 40db より良好のもの，図23に は 40db 糰力がより不良のものを集めている。この両図 に集計された症例は，骨導值が注ば正常に近いもののみ である.

図22を見ると極めて特幑的な 聴力像である、すなわ b，聉力像怯凸型であり，冖のピークが 1,500 cps と 2,000cps のいずれか一方，又はその雨者によつて形成さ
图 22 退院㭙愦力

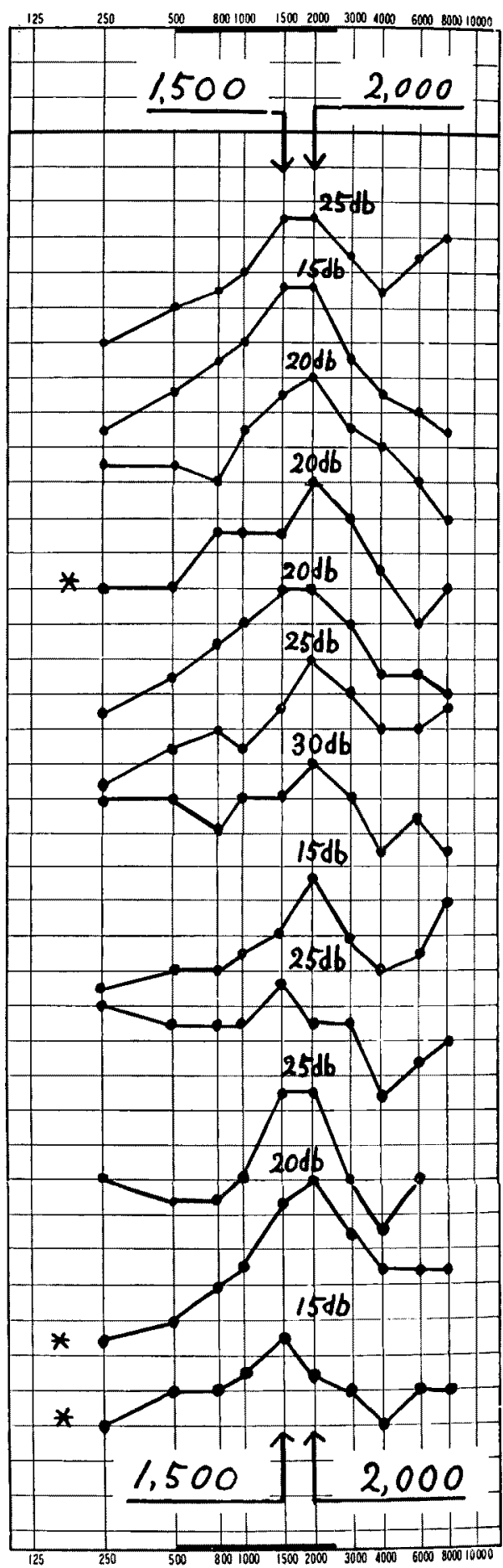

$40 \mathrm{db}$ 以上の N 型症例の聴力型。各聴力像に附 記した $\mathrm{db}$ 数は，最良聴力を示す周波数の db 数を示す。*; 静脈片使用例 
图 23 退院時㥁力

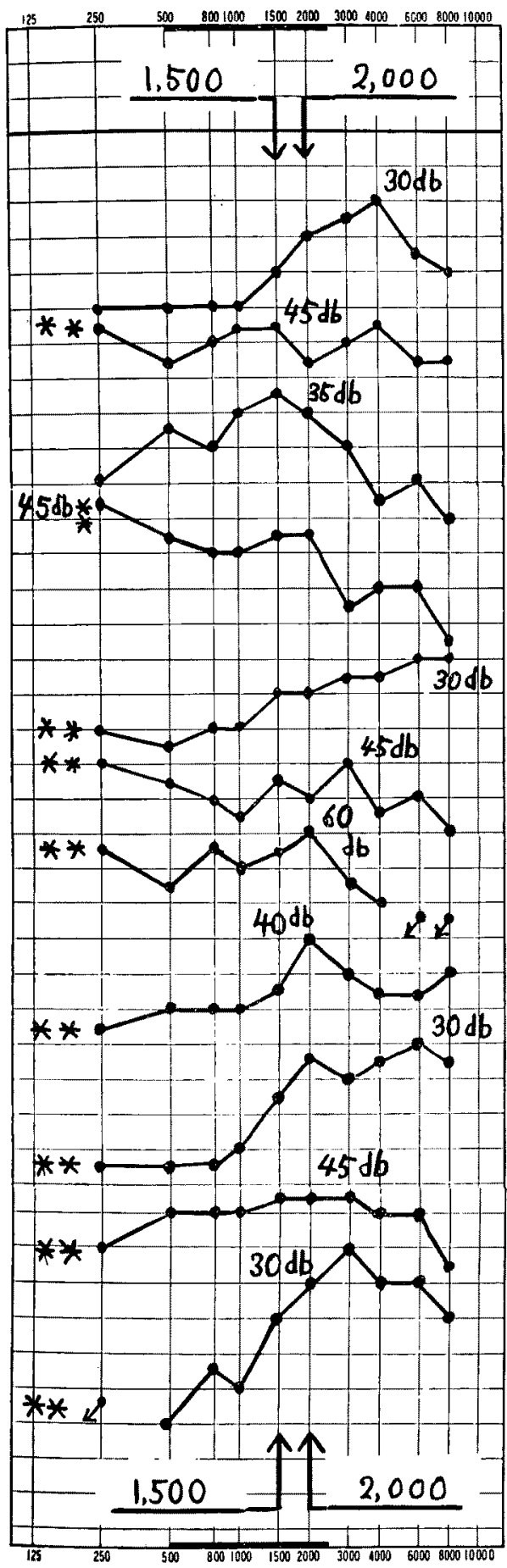

40db 以下のN型店例の聴力型. **; 鼓室徽底 清搰を行つた症例.
れている、この聴力像㣖図 23 の中の粘膜保存 N 型にも 見出されている。

以上の如き特巽なピークを有する德力像は，跂室粘膜 を除去したN型には㱠ど見出されておらない。かように cavum minor の形成に不利な条件では特異なピークの 出現が殆どなく，有利な条件では特翼なピークが殆ど必 発的に出現することは大変㺞味がある，そこで従来の諸 報告から型の聴力像を調查してみた。

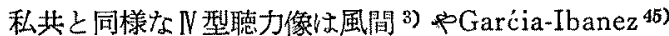
の症例で明膫である。さた不明膫ながらる Wullstein 46) と Schuknecht \& Oleksiuk 47) の症例炕散見する.

しかし Wullstein ${ }^{46)} の 3$ 症例 (聴力夫々 $15 ， 30$ 㝊 び 34db)ではピークがなく，また彼の他の1症例（聴 力 $20 \mathrm{db})^{48)}$ では高音急憼型である. Kley ${ }^{44)}$ の2 症例 （聴力夫々 5 及び $22 \mathrm{db}$ ）では 2 症例とも型の聴力像を 示しすこぶる特異である. Ormerod \& McLay 50)の1 症例（聴力 $32 \mathrm{db}$ )では 1,000 cps に不明膫なピークが でている.

Richtner ${ }^{51)} の 1$ 症例 (德力 $22 \mathrm{db}$ ) は flat な㯖力像， Wiegand の 1 症例 (聴力 $24 \mathrm{db}$ ) は flat, 他の 1 症例 （聴力 $24 \mathrm{db}$ ）では漸傾型の聴力像である.Wullstein ${ }^{53)}$ の此較的新しい 2 症例（恥力夫々 16 及び $18 \mathrm{db}$ ) では， 第 1 例が Alat，第 2 例が 2,000 cps に不明瞭なピークを 有する聴力像である。調と村島 ${ }^{54)}$ の2 症例（聴力夫々

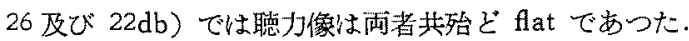

骨導低下している症例にN 型を行つてみると，特徽的 な $1,500 \mathrm{cps}$ 又は $2,000 \mathrm{cps}$ のピークを聴力像に見出し 得ないことがある。

図 24 の症例は，術前骨尊は正常に近かつたが入院中 に両耳骨導が急激に低下したものがある。雨耳共病変阅 度で，鼓空の微底的清掃を行つて静脈片の移植を行つ た.この症例では雨耳共その㯖力像に特致的なピークが 認められた。

図 25 の症例は, 術前既に骨毞の低下があつたもので, 雨耳共静脈片の移植を受けたものである，この症例では 右耳の聴力像に 4,000 cps の異常ピークを認め, 左耳の

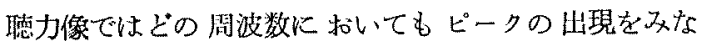
w.

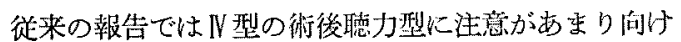
られていなからた，骨筫正常耳に対し，粘膜保存あるい は静脈片移植等によつてN $N$ 型手術を行らと，退院時の㯖 力像に特徽的なピークが現われ，遠隔成績に打いてもこ の傾向が明らかに観察される，乙かし従来の交献による 
图 24 豊○洋○

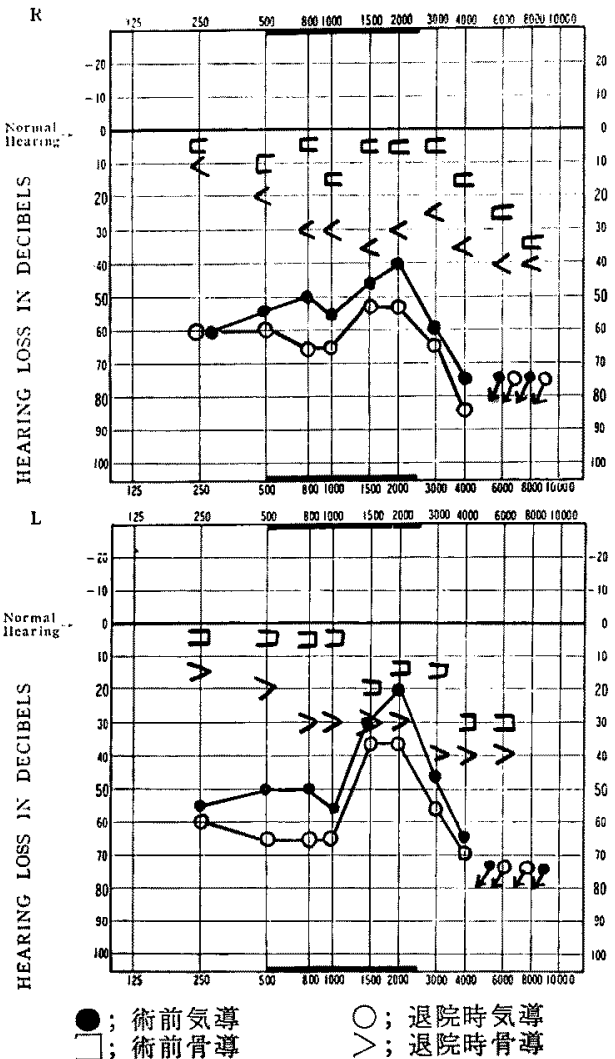

国 25 井○秀

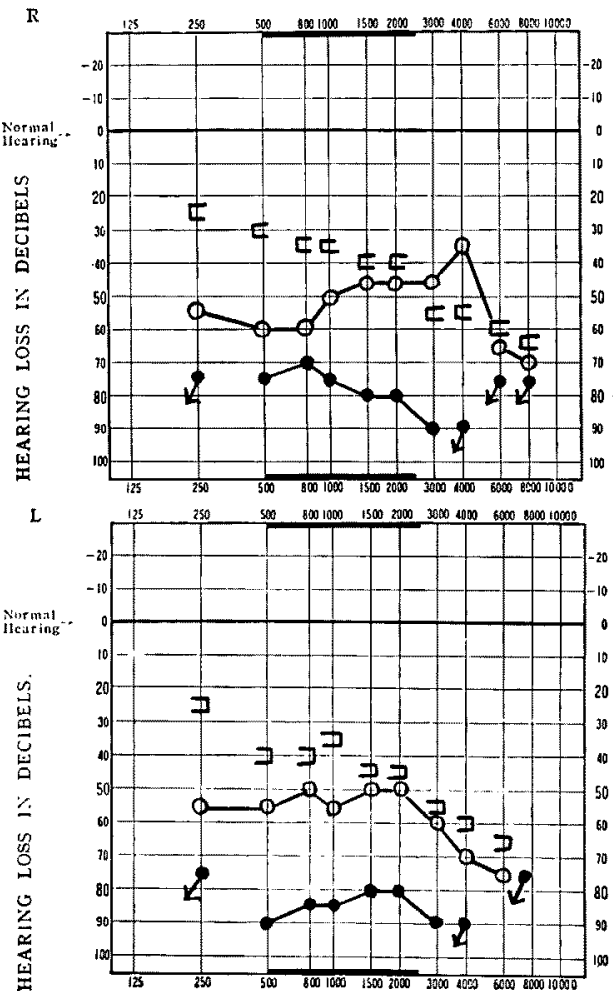

；術前気導， $\bigcirc$; 退院時気導， 口; 術前骨道
と，若干の術者を除いては私共のものと全く異る聴力像

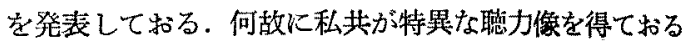
か直らには理解し難い：この点について更に症例を重如 て検討したいと考劣ている。

\section{稳括}

（政室成形術の基本的手術体系）

多彩な病変, 複雑な要因の介在する中耳炎の手術にお。 いて，画一的な手術を行つたのではらまくゆくはずはな い. 症例の 1 つ つに思いを新たにし，充分な観察と創 意工夫の下に手を術進めるべきである.かくして，複墔 な臨床の中にもある種の手術理論が得られ，これによつ て手術の基本的体系が組み立てられよう．ここに本椧文 の総括として，手術に対する私共の基本的方針を述へて みたい。

図 26 鼓室成形術の各型と，それに よる術後期待聴力籍囲

(db)

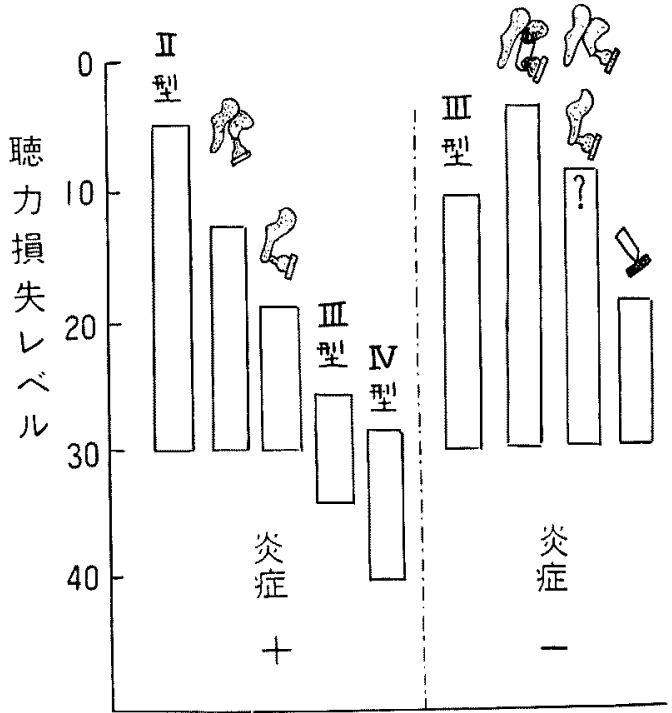

豉室成形術では，術後德力を良好ならしめる要点は， 鼓膜皮弁と鼓室岬との距睢をなるべく大さくとれるよう な型に手術をむつて行くことにあると思う．図26をみ れば明瞭であるが，一般には】型の成績が最も良好であ る。これに次ぐものは incudostapediopexyで，その次 に malleolostapediopexy が位する. 四型は前了者に比 べ成續が少り，更にN 型は II より不既である、いらなれ ば，鼓室成形術では型やN型に手術をもちこまないよ ら㶧夫するのが大切と云える。 
この見地から，耳小骨の保存が非常に大切な手術手拔 となる。止もを得す耳小能を除去する場合には砧骨に止 むべきで，砧骨は極力殖監利用した方がよい，耳小骨は その表面の粘膜涪っつて栄羡を受けておるので，耳小骨 を殖置する場合，表面粘裳はとのまま保存することが重 要である、これらのことが耳小骨を处理する上の基本的 方針と考党ている。

晊室に炎㱏のあるものとないるのとでは，手術の形は 同じでる内容的には異質の手術と考え方がよい，最も大

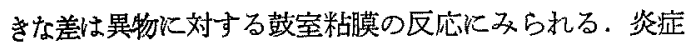
のないるのでは，異物を㨉入してむ組織反応恃殆ど拈こ らす経過は順調であるが，炎症のあるるのに異物を择入 すると激しい異物反応を括こし，異物周辺に大量の肉茅 の発生をみる，遊離した自家骨も炎症のある鼓室には異 物となるので注意を要する。

鼓室に炎症のあるものとないものとでは手術成績にも 影響し，特に血型に括いて顕著である。すなわち，炎症 のない故室に自型を行らと，その成績は大変良好でI 型 の場合にさして劣らない，炎症のある場合には型の成 續はあまり良好でない，すなわち，回型の手術成續の向 上のためには，まず鼓室の炎症を治癒してかかるのが最 善の方策と思われる， I 型の場合には耐性菌感染耳は別 として，鼓空の炎症の有無は手術成績に左程大きな影響 をもたなかつた． II型ではこれが大きく影響するので，

I型と】型の手術適応は別個に考慮さるべきである.

図26がいわば私共の鼓室成形の手術体系である、こ れ汇よつて手術の基準をきめて括るが，問題は完全耐性 菌による感染であると思う。この菌による感染耳の手術 成績はよろしくない，この問題をいか沉解決するかは今 後の研究にまっところ大である。

\section{主要文献}

1) 田坂正堂：鼓室成形術に関する細菌学的研究，日 耳年，65:844，853，1962（昭37)。2）西端八郎：鼓 室の病熊粘膜に対する処理並びに根治手術との比較につ いて, 耳喉科，34:867，1962 (昭37). 3) 風間保彦: 最近 6 年間の鼓室成形手術 (風間法) 耳喉科， $34: 917$, 1962 (昭37)，4）後藤修二, 板合秀: 中耳形成手術 1 年挠の成絽，耳喉科，29:33，1957(呢32).5) 後

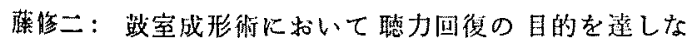
い堵合及びその処理 (3)，手術，18:513，1964（昭39). 6) Zöllner, F.: The principle of Plastic Surgery of the Sound-Conducting Apparatus. J. Laryng. Otol., 69:687, 1955. 7) Hall, A., and Rytzner,
C.: Stapedectomy and Autotransplantation of Ossicles. Acta Otolaryng., $47: 318,1957 . \quad$ 8) Bell, H.L.: Technique of Tympanoplasty. A.M.A. Arch. Otolaryng. 66: 554, 1957, 9) Westrow, F.: Besondere Formen der Tympanoplastik bei Unterbrechung der Schalleitung im Bereich des Amboss. Arch. Ohren-usw. Heilk, u Z. Hals-usw. Heilk.,

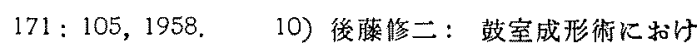

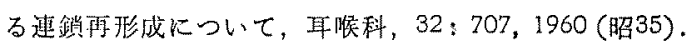
11) Farrior, J.B.: Ossicular Repositioning and Ossicular Prosrheses in Tympanoplasty. A.M.A. Arch. Otolaryng., 71 ：443, 1960, 12) 高原滋夫: 聴力增進を目標とした敋室成形術の適応，耳喉科，34： 891,1962 (昭37)。13) 黑住静之, 金谷真, 益田弦: 残存耳小骨, Polyethylene Tube, Tantalum Wire $k$ よるコルメラ形成，耳矨科，34：873，1962(昭37). 14) 森本正紀: 鼓室形成術の適応, 耳喉科，34:895,

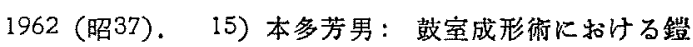
骨外科の経験，耳喉科，34:989，1962 (昭37)。1 16) Guilford, F.R.: Tympanoplasty: Use of Prostheses in Conduction Mecnanism. A.M.A. Arch. Otolaryng., 80:80, $1964 . \quad 17)$ Rubinstein, M., Korine, E., and Eviatar, C.: Malleolostapedial Transposition of Midddle Ear Surgery. A.M.A. Arch. Otolaryng., $80: 38,1964 . \quad 18)$ Sataloff, J.: Repair of Ossicular Defects with Ostamer. A.M.A. Arch. Otolaryng., 70:415, $1959 . \quad 19)$ Harrison, W.H., Shambaugh, G.E. Jr., Kaplan, J, and Derlacki, E.L.: A.M.A. Arch. Otolaryng., 69: 661, 1959. 20) House, H.P.: Unfavorable Results of Stapes Mobilization Surgery. A.M.A. Arch. Otolaryng., $71: 312,1960.21)$ 寺山邦昭, 寺山喬子：Polyethylene Tube による Columella Prosthesis. 耳奥臨 床, $57 \cdot 158,1964$ (昭39). 22) Baron, S.H., and Lindsay, J.R.: Stapedectomy with Fat Graft and Polyethylene Strut. A.M.A. Arch. Otolaryng., 80 : 128, 1964. 23) Scheer, A.A.: The Use of a Prosthesis in Stapes Mobilization. A.M.A. Arch. Otolaryng. 70:551, 1959 . 24) Shea, J.J.: Fenestration of the Oval Window. Acta Oto-laryng., 51 : 99, 1960. 25) Derlacki E.L.: Chisel Techniques for Stapes Mobilization. A.M.A. Arch. Otolaryng., $71: 271,1960.26)$ Sooy, F.A., Barios, X., Ham- 
bly, W., and Burn, H.: A Clinical and Laboratoy Evaluation of Polyethylene Tubinig in Mddle Ear Surgery. Ann. O.R.L., 70: 808, 1961. 27) Steffen, T.N., House, P.H., and Sheehy, J.L.: The Slipped Stut Problem. Ann. O.R.L., 72: 191, 1963. 28) Schuknecht, H.F. and Oleksiuk, S.:

The Metal Prosthesis for Stapes Ankylosis A.M.A. Arch. Otolaryng, $71: 287,1960 . \quad 29)$ Ehmke, O.: Platinum Stapedial Prosthesis in Middle Ear Surgery. A.M.A. Arch. Otolaryng., 79 : 54, 1964 . 30) Raymond-Jones, R.T.: Stapedectomy Using New Material to Replace Stapes. A.M.A. Arch. Otolaryng., 80:131, 1964, 31) Zöllner, F.: Hörbessende Operationen bei entzündlich bedingten Mittelohrve. ränderungen. Arch Ohren-usw. Heilk, u.Z. Halsusw. Heilk., 171: 1, 1957. 32) House, H.P.: Polyethylene in Middle Ear Surgery. A.M.A. Arch. Otolaryng., 71 : 926, 1960. 33) Lindsay, J.R.:

Histopathologic Findings Following Stapedectomy and Polyethylene Tube Inserts in Man. Ann. O.R. L. 70:779,1961. 34) Harris, A.J.: Experimental Findings Following the Stapes Replacement Procedure. Laryngoscope 71: 131, 1961. 35) Goldman, J.L., Nalebuff, D.J., and Druss, J.: Experimental Observationson Prosthetic Materials in Stapedial Surgery with Special Reference to the Use of Teflon. Laryngoscope $72: 169,1962$. 36) Harrison, W: Prosthetics in Tympnoplasty. A.M.A. Arch. Otolaryng. 71: 437, 1960.

37) Hohman, A., Hilger, J.A., and Carley, R.: Fate of Implants in Rats. Ann. O.R.L., 73: 791, 1964, 38) 作藤正明：

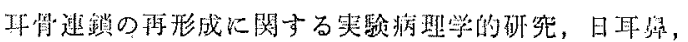
62: 2396, 1959 (1434). 39) Nager, G.T., and Nager, M.: The Arteries of the Human Middle Ear, with Particular Regard to the Auditory Ossicles. Ann. O.R.,L., $62: 923.1953$. 40) Hamberger, C.A., and Wessall, J.: Vascular Supply of the Tympanic Membrane and the Ossicular Chain.
Acta Otolaryng. Suppl. 188: 308, 1963. Anson, B.J., Harper, D.G., and Winch, T.R.: Intra-Osseous Blood Supply of the Auditory Ossicles in Man. Ann. O.R.L., 73: 645, 1964. Lindeman, H.: Some Histologic,al Examinations of the Incus and Stapes with Especial Regard to their Vascularization. Acta Otolaryng., Suppl., 188: 319, 1963. 43) Freckner, P.: Tympanoplasty: Surgical Aspects and Experiences. Acta Otolaryng. 48: 277, 1957. 44) Wullssein, H.: Tympanoplasty: The Problem of the Free Graft and the Mucous Membrane Graft. A.M.A. Arch. Otolaryng., 71: 363, 1959. 45) Garćia-Ibanez, L.: Surgical Hearing Rehabilitation of the Chronic Supprating Middle Ear. A.M. Arch. Otolaryng., 70: 8, 1959. 46) Wullstein, H.: The Restoration of the Function of the Middle Ear, in Chronic Otitis Media. Ann. O.R.L. 65: 1020, 1956, 47) Schuknecht, H.F., and Oleksiuk, S.; Tympanoplasty. Laryngoscope 69 : 614, 1959. 48) Wullstein, H.: Theory and Practice of Tympanoplasty. Laryngoscope 66: 1076, 1956. 49) Kley, W.: Problem der Tympanoplastik. Z. Laryng., 34: 719, $1955 . \quad 50)$ Ormerod, F.C., and McLay, K.: The Technique of Plastic Operations on the Sound Conducting Apparatus. J. Laryng. Otol., 700: 648, 1956, 51) Richtner, G.N.: On Plastic Middle Ear Operations with Particular Attention to the Cavum Minor Technis que. Acta Otolaryng., 48:302, 1957. 52) Wiegand, H.: Tympanoplastic Operations. A.M. Arch, Otolaryng., 67:239, 1958, 53) Wullstein, H.: Results of Tympanoplasty. A.M.A. Arch. Otolaryng.,

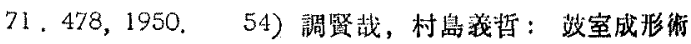
N 型に刘する私洪の考方方と術後成絖，呕喉科，35 443,1963 (昭38).

（原储到着二㗁和 39.1 .16 日) 